
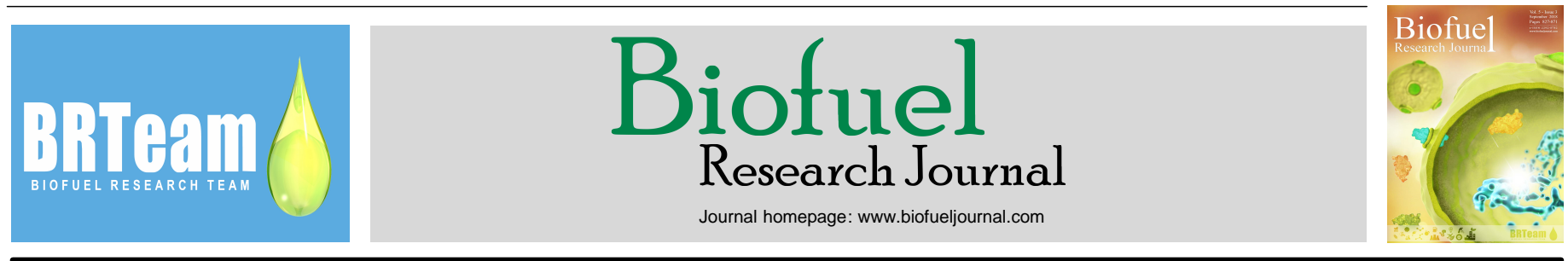

Review Paper

\title{
Fueling the future; plant genetic engineering for sustainable biodiesel production
}

\author{
Gholamreza Salehi Jouzani*, Reza Sharafi, Saeed Soheilivand \\ Department of Microbial Biotechnology, Agricultural Biotechnology Research Institute of Iran (ABRII), Agricultural Research, Education and Extension
}

Organization (AREEO), P.O. Box: 31535-1897, Karaj, Iran.

\section{HIGHLIGHTS}

$>$ Genetic engineering potentials to enhance oil production in emerging nonedible oil plants for economic biodiesel production were discussed. $>$ Expression, overexpression, or suppression of major genes affecting oil yield, oil composition, and were reviewed.

$>$ Major genes widely used to enhance oil content and composition were reviewed.

$>$ Challenges in commercialization of GM oil plants were presented. tolerance to biotic/abiotic stresses in bioenergy crops

\section{GRAPHICAL ABSTRACT}

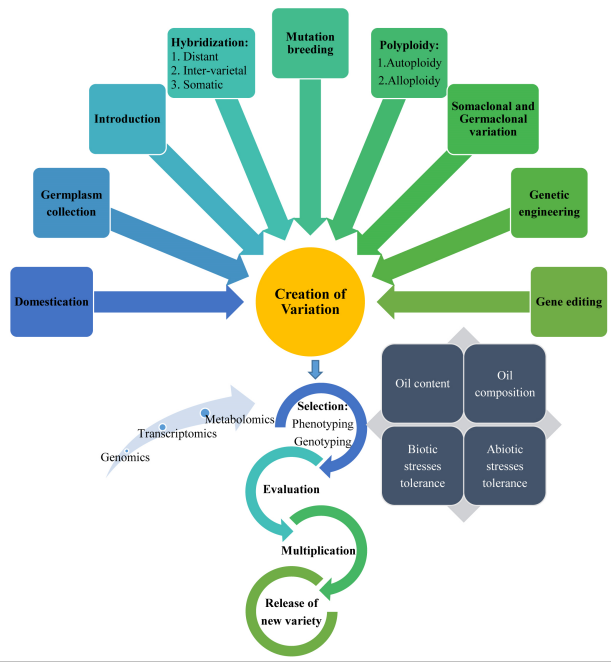

\section{ARTICLE INFO}

\begin{abstract}
Biodiesel has huge potentials as a green and technologically feasible alternative to fossil diesel. However, biodiesel production from edible oil crops has been widely criticized while nonedible oil plants are associated with some serious disadvantages, such as high cost, low oil yield, and unsuitable oil composition. The next generation sequencing (NGS), omics technologies, and genetic engineering have opened new paths toward achieving high performance-oil plants varieties for commercial biodiesel production. The intent of the present review paper is to review and critically discuss the recent genetic and metabolic engineering strategies developed to overcome the shortcoming faced in nonedible plants, including Jatropha curcas and Camelina sativa, as emerging platforms for biodiesel production. These strategies have been looked into three different categories. Through the first strategy aimed at enhancing oil content, the key genes involved in triacylglycerols (TAGs) biosynthesis pathway (e.g., diacylglycerol acyltransferase (DGAT), acetyl-CoA carboxylase (ACCase), and glycerol-3-phosphate dehydrogenase (GPDI)), genes affecting seed size and plant growth (e.g., transcription factors (WRII), auxin response factor 19 (ARF19), leafy cotyledon1 (LEC1), purple acid phosphatase 2 (PAP2), G-protein c subunit 3 (AGG3), and flowering locus $\mathrm{T}(F T)$ ), as well as genes involved in TAGs degradation (e.g., sugar-dependent protein 1 triacylglycerol lipase $(S D P I)$ ) have been deliberated. While through the second strategy targeting enhanced oil composition, suppression of the genes involved in the biosynthesis of linoleic acids (e.g., fatty acid desaturase (FAD2), fatty acid elongase (FAE1), acyl-ACP thioesterase (FATB), and ketoacyl-ACP synthase II $(K A S I I)$ ), suppression of the genes encoding toxic metabolites (curcin precursor and casbene synthase (JCCASA)), and finally, engineering the genes responsible for the production of unusual TAGs (e.g., Acetyl-TAGs and hydroxylated fatty acids (HFA)) have been debated. In addition to those, enhancing tolerance to biotic (pest and disease) and abiotic (drought, salinity, freezing, and heavy metals) stresses as another important genetic engineering strategy to facilitate the cultivation of nonedible oil plants under conditions unsuitable for food crops has been addressed. Finally, the challenges faced prior to successful commercialization of the resultant GM oil plants such have been presented.
\end{abstract}

(C) 2018 BRTeam. All rights reserved.

* Corresponding author at: Tel.: +98 2632703536

E-mail address: gsalehi@abrii.ac.ir

Please cite this article as: Salehi Jouzani G., Sharafi R., Soheilivand S. Fueling the future; plant genetic engineering for sustainable biodiesel production. Biofuel Research Journal 19 (2018) 829-845. DOI: 10.18331/BRJ2018.5.3.3 


\section{Contents}

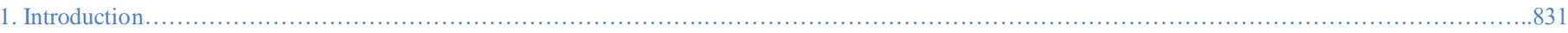

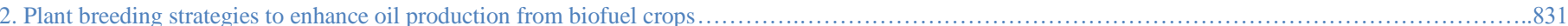

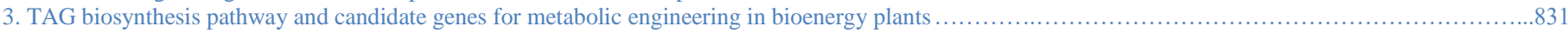

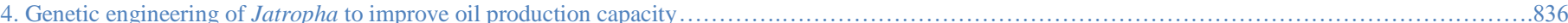

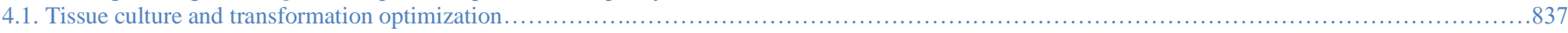

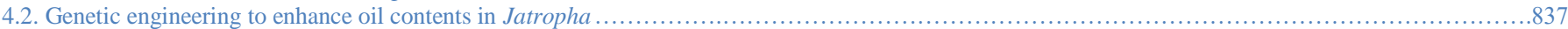

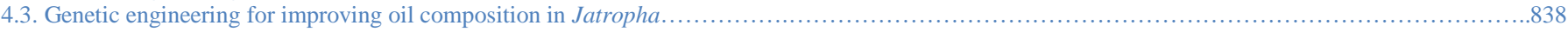

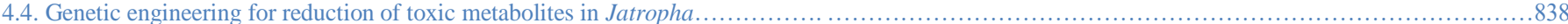

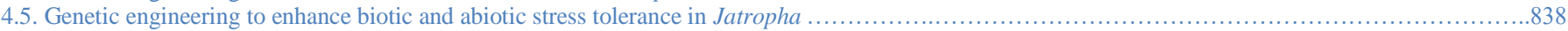

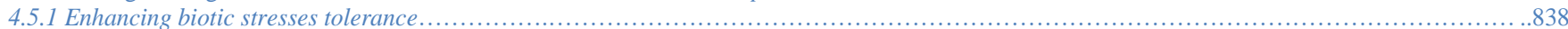

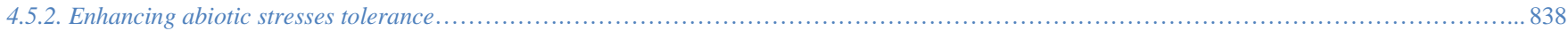

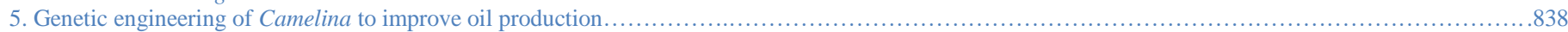

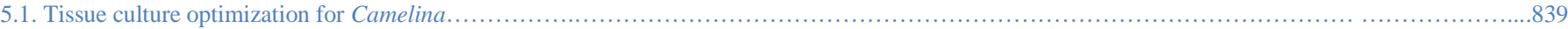

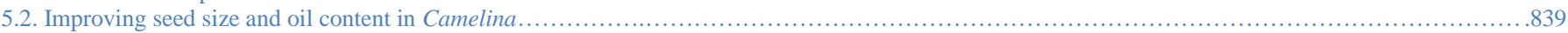

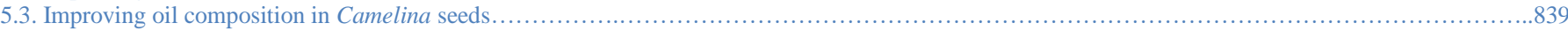

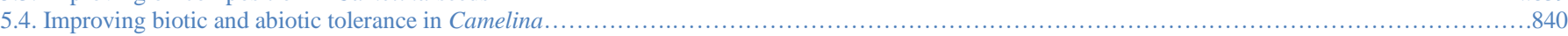

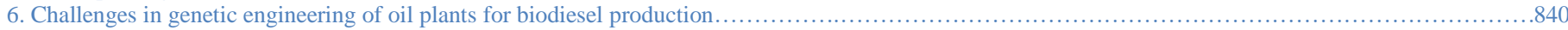

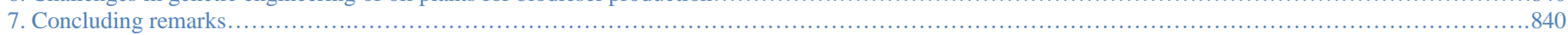

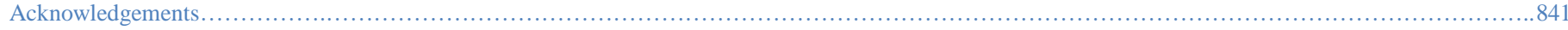

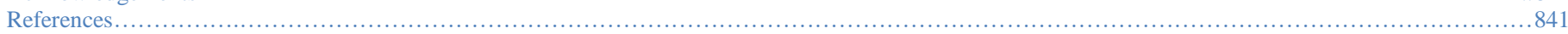

\begin{tabular}{|c|c|c|c|}
\hline Abbreviations & & Abbreviations & \\
\hline ACC & Acetyl-CoA carboxylase & GS & Genomic selection \\
\hline ACCase & Acetyl-CoA carboxylase & HFA & Hydroxylated fatty acids \\
\hline $\mathrm{ACP}$ & Acyl carrier protein & $J c D G A T 1$ & Jatropha curcas diacylglycerol acyltransferase \\
\hline ARF19 & Auxin Response Factor 19 & KASIII & $\beta$-ketoacyl-ACP synthase III \\
\hline$A t P A P 2$ & Arabidopsis thaliana purple acid phosphatase 2 & LEC1 & Leafy cotyledon 1 \\
\hline AtWRII & Arabidopsis thaliana WRINKLED 1 & LPAAT & Lyso- phosphatidic acid acyltransferase \\
\hline CsDGAT1 & Camelina sativa diacylglycerol acyltransferase 1 & LPCAT & LPCAT: lysophosphatidylcholine acyltransferase \\
\hline DAG & Diacylglycerol & MAS & Marker-assisted selection \\
\hline DGAT & Diacylglycerol acyltransferase & MCFAs & Medium chain fatty acids \\
\hline DHAP & Dihydroxyacetone phosphate & NGS & Next generation sequencing \\
\hline EST & Expressed sequence tag & PAD4 & Phytoalexin deficint 4 \\
\hline$F A$ & Fatty acid & PAP & Phosphatidic acid phosphatas \\
\hline FatA & Fatty acyl acyl carrier thioesterase A & $P P A T$ & Phosphopantetheine adenylyltransferase \\
\hline$F A T B$ & Acyl-ACP thioesterase & PR & Pathogenesis-related \\
\hline$F D S$ & Farnesyl diphosphate synthase & PUFA & Polyunsaturated fatty acid \\
\hline$F T$ & Flowering locus $T$ & $Q T L$ & Quantitative trait locus \\
\hline$G D H$ & Glycolate dehydrogenase & RNAi & RNA interference \\
\hline$G D P$ & Geranyl diphosphate synthase & ROS & Reactive oxygen species \\
\hline GGCT2 & $\gamma$-glutamyl cyclotransferase gene & SAD & Stearoyl desaturase \\
\hline GHG & Greenhouse gasses & SDP1 & Sugar-dependent protein 1 triacylglycerol lipase \\
\hline GHPD1 & Glycerol-3-phosphate dehydrogenase & SNP & Single nucleotide protein \\
\hline$G L C$ & Glyoxylate carboligase & SPS & Sucrose phosphate synthase \\
\hline GM & Genetically modified & TAG & Triacylglycerol \\
\hline GPAT & Glycerol-3-phosphate acyltransferase & TRS & Tartonic semialdehyde reductase \\
\hline
\end{tabular}




\section{Introduction}

Based on recent predictions, the world population will significantly increase up to 9 billion people by the year 2050. This will cause further rapid increases in energy demands, significant decreases in the global fossil fuel reserves, and the intensification of the global environmental challenges such as global warming and climate change due to increased emission of greenhouse gasses (GHG). Given the diminishing sources of fossil fuels as well as the nonrenewable and unsustainable nature of these fuels, it is necessary to find alternative sources of energy. In fact, seeking renewable energies with less GHG emissions and air pollution capacity is of importance at global level (OECD, 2012). Among different renewable platforms, biomass-based energy production has attracted a great deal of attention because of the huge quantity of biomass (e.g., plants and residues) produced globally and the potentials it holds to mitigate the harmful environmental impacts associated with fossil fuels (Tabatabaei et al., 2011; Salehi Jouzani and Taherzadeh, 2015; Selim, 2015; Zahed et al., 2016).

Among various biomass-oriented fuels, biodiesel has been considered to have great potentials as a green and technologically-feasible alternative to fossil diesel fuels. Biodiesel is derived from plant seed oils and animal fats and is a mixture of the alkyl esters if long chain fatty acids, mainly produced by transesterification methodology. The physico-chemical properties of biodiesel are very similar to those of petroleum diesel, and therefore, could be used as an alternative to diesel in conventional diesel engines without the need for any modifications. Other advantages of biodiesel include higher cetane number, flash point and lubricity, absence of sulfur, and lower aromatics content compared to the petroleum diesel (Demirbas, 2009; Tabatabaei et al., 2011; Axelsson et al., 2012; Lee and Lavoie, 2012)

Biodiesel is mostly produced from the edible oils, i.e., soybean, canola, rapeseed, palm, etc. (Hegde et al., 2015; Taher and Al-Zuhair, 2017). However, the application of such oil crops as feedstock for biodiesel production is associated with negative impacts on global food security, especially in the developing world suffering from vulnerable economy and agriculture. On the other hand, given such unfavorable effects on the price of food commodities and consequently food security, biodiesel production from food-grade feedstock may not be quite economically feasible either. Therefore, nonedible oils, animal waste fats, and used vegetable oils have been used for biodiesel production. The most important nonedible oil plants with high potentials for biodiesel production include physic nut (Jatropha curcas), Camelina (Camelina sativa), castor beans (Ricinus communis L.), neem (Azadirachta indica A.), karanja (Pongamia pinnata L.), mahua (Madhuca spp.), simarouba (Simarouba glauca DC.) and cheura (Diploknema butyracea). However, current oil yields from these plants are in general insufficient to meet the bioenergy demands, while the resultant oils are characterized with trace salts, water, and high free fatty acid contents. Thus, genetic improvements to enhance their oil yield and properties has attracted a considerable deal of attention (Alaba et al., 2016; del Pilar Rodriguez et al., 2016).

During the last decades, different plant breeding strategies have been used to improve oil yield and quality and to also improve tolerance to biotic and abiotic stresses in edible and nonedible oil plants. New biotechnological tools such as marker-aided selection, next generation sequencing, "omics" technologies, and genetic engineering have accelerated the breeding process for such traits in these kinds of plants. Identification and isolation of major genes involved in the lipid biosynthesis pathways using omics technologies and their transfer to edible and no-edible oil plants are expected to result in economical oil production in such plants as feedstock for biodiesel production (Grover et al., 2013). Different genetic engineering strategies aimed at changing the structure of the enzymes as well as overexpression or silencing of the genes involved in the oil production pathway have been used to enhance oil yield and quality in nonedible oil plants. In this article, recent advances in the field of plant genetic engineering for improving oil production in biofuel crops and in particular in tow of the most promising non-edible plants, i.e., Jatropha and Camelina are reviewed and discussed. Moreover, the challenges faced and the future prospects of these strategies in improving biodiesel production are presented.

\section{Plant breeding strategies to enhance oil production in biofuel crops}

To achieve commercial biodiesel production from nonedible oil plants, development of new varieties/hybrids of oil plants with high oil contents, tolerance to biotic and abiotic stresses, and no toxic proteins is a critica step. During the last decades, different breeding strategies have been used to improve these traits in edible and nonedible oil plants. The main activities pursued in plant breeding include developing variation, selection, evaluation for target traits, multiplication, and finally, release and distribution of new varieties (Fig. 1). Commonly, creation of genetic variation is performed through domestication, germplasm collection, introduction, intra- and inter-species hybridization, mutation, polyploidy, somaclonal variation, germaclonal variation, and genetic engineering (Singh and Nimbkar, 2006; Singh et al., 2015; Moniruzzaman et al., 2016). During the last decades, using conventional breeding strategies, different edible and nonedible oil plants have been improved to enhance oil quality, oil yield, and tolerance to biotic and abiotic stresses (Golkar, 2014 Merkouropoulos et al., 2016; Montes and Melchinger, 2016; Valliyodan et al., 2017). In spite of such successful experiences, these methods face some disadvantages, such as being laborious and time-consuming, low accuracy in achieving desired traits, impossibility of inter-species hybridizations and wild crosses.

Recent developments in next generation sequencing technologies (NGS) have encouraged rapid development of bioenergy crops. Different new "omics" technologies (genomics, transcriptomics, metabolomics, and metagenomics), marker-aided selection (MAS) and genetic engineering approaches have been considered and are widely used as the most promising solutions to improve agronomic traits in bioenergy oil plants. "Omics" technologies could be used to identify genes involved in oil production, to discover oil production pathways, and also to improve oil content and composition. To facilitate such efforts, whole genomes of some oil plants including soybean (Schmutz et al., 2010), rapeseed (Wang et al., 2011), sunflower (Staton et al., 2012), Arabidopsis (Cao et al., 2012), castor bean (Chan et al., 2010), Jatropha (Sato et al., 2011; Wu et al., 2015), Pará rubber tree (Hevea brasiliensis) (Rahman et al., 2013), oil palm (Elaeis guineensis) (Singh et al., 2013; Pootakham et al., 2015), Asian spicebush (Lindera glauca) (Lin et al., 2017), Camelina (Mudalkar et al., 2014), and P. pinnata (Jiang et al., 2017) have been already sequenced. Such huge deal of data has opened a new high throughput way to discover genes and pathways involved in oil production as well as the genes affecting oil quality in these plants. Moreover, by using omics technologies, such as quantitative trait locus (QTL) mapping, single-nucleotide polymorphism (SNP) and expressed sequence tag (EST)-based molecular markers, cDNA libraries, and RNA-seq analysis, researchers could identify and characterize genes involved in lipid synthesis pathways, tolerance to biotic and abiotic stresses, and the other important traits (Tang et al., 2007; Liu et al., 2011 and 2017; Tian et al., 2016).

\section{TAG biosynthesis pathway and candidate genes for metabolic engineering in bioenergy plants}

Identification and characterization of the key genes involved in the performance of such important agronomical traits are the first critical steps for breeding programs in oil crops. Triacylglycerols (TAGs) are the major seed storage lipids and are used as energy and carbon sources during the seed germination process. TAG biosynthesis pathway in the higher plants seeds is very complex (Fig. 2). Recently, some comprehensive reviews have been published presenting more detailed description on this complex pathway (Bates and Browse, 2012; Bates et al., 2013; Bansal and Durrett, 2016).

The first step of lipid production in plants is fatty acid (FA) synthesis. Acetoacetyl- acyl carrier protein (Acetoacetyl-ACP) as a key substrate is necessary to initiate the process of FAs biosynthesis. Two enzymes have key roles in the conversion of Acetyl-coenzyme A (Acetyl-CoA) to acetoacetyl-ACP. The first enzyme is acetyl-CoA carboxylase (ACC), which catalyzes the conversion of acetyl-CoA to malonyl-CoA. Subsequently, the second enzyme, i.e., $\beta$-ketoacyl-ACP synthase III (KASIII) catalyzes the conversion of malonyl-ACP to acetoacetyl-ACP. Then, two carbon units are added elongating the FA chain through repeated condensation, reduction, and dehydration reactions (Sainger et al., 2017). Diacylglycerol (DAG) is the immediate precursor molecule for TAG biosynthesis. Two main pathways have been identified for DAG biosynthesis, which include de novo DAG synthesis (Kennedy pathway) and/or conversion of phosphatidylcholine (PC). The FA modification 


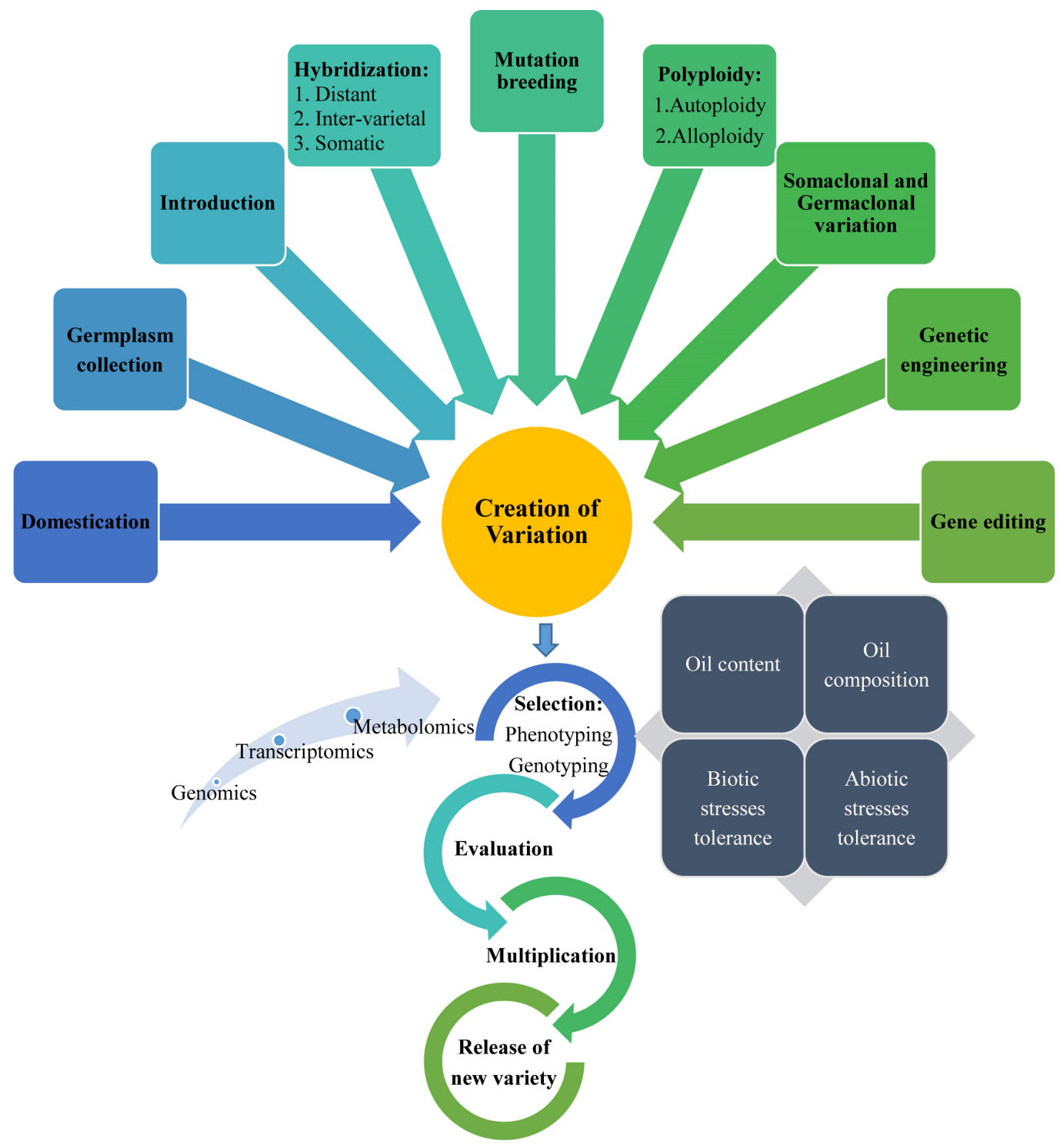

Fig.1. Main plant breeding activities to develop variation followed by selection, evaluation for target traits, multiplication, and finally, release and distribution of new varieties.

(desaturation, hydroxylation, etc.) occurs only for those FAs which are esterified to PC, thus, the FA composition of PC-derived DAG can be substantially different from that of de novo DAG. As DAG provides two of the three FAs in the TAG structure, the relative flux of TAG synthesis from PCderived or de novo DAG can significantly affect the final oil composition (Bates et al., 2013; Bansal and Durrett, 2016; Sainger et al., 2017). The TAG biosynthesis pathways and the candidate genes which can be used for bioengineering to enhance oil yield and quality are summarized in the Figure 2.

During the last decades, genetic and metabolic engineering approaches have shown huge potentials to accelerate achieving breeding targets for different crops (Salehi Jouzani et al., 2008; Safarnejad et al., 2011; Salehi Jouzani, 2012; Tohidfar et al., 2013). In this regards, different GM strategies have been used to enhance oil yield and oil composition to make oil crops suitable for biodiesel production. These include, 1) increasing oil contents as well as seed and fruit size, 2) improving oil composition, 3) improving biotic and abiotic tolerance, and 4) reduction of toxic metabolites in oil crops. The first strategy is the most important methodology in which the genes encoding proteins involved in the oil biosynthesis pathways as well as those involved in seed/fruit size and plant growth are used as candidate genes. This methodology includes improving TAG synthesis by overexpression of the genes involved in the oil biosynthesis (such as DGAT, GPD, FatA, and LPAT), inhibition of TAG degradation (suppression of the sugar-dependent protein 1 triacylglycerol lipase (SDP1)), using different types of transcription factors (overexpression of WRI1 transcription factors), and improving morphological and developmental traits by expression of different genes encoding auxin response factor 19 (ARF19), Zea maize leafy cotyledon 1 (LEC1), purple acid phosphatase 2 (AtPAP2), G-protein c subunit 3 (AGG3), early flowering (flowering locus $\mathrm{T}(J C F T)$ ), and photo respiratory bypass bacterial genes $(G D H, G L C$, and $T R S)$ (Table 1).

Improvement of seed oil content through engineering of lipid biosynthetic pathways is known as the simplest and the most efficientgeneti engineeringstrategy to enhance economically-feasible oil production in nonedible plants (Hegde et al., 2015). For instance, DAG acyltransferase gene (DGAT) encodes a salient enzyme, which is involved in TAG biosynthesis, and has an important role during oil production in plants. The conversion of DAG and free fatty acids to TAG is catalyzed by DGAT during the storage oil synthesis (Andrianov et al., 2010; Chhikara et al., 


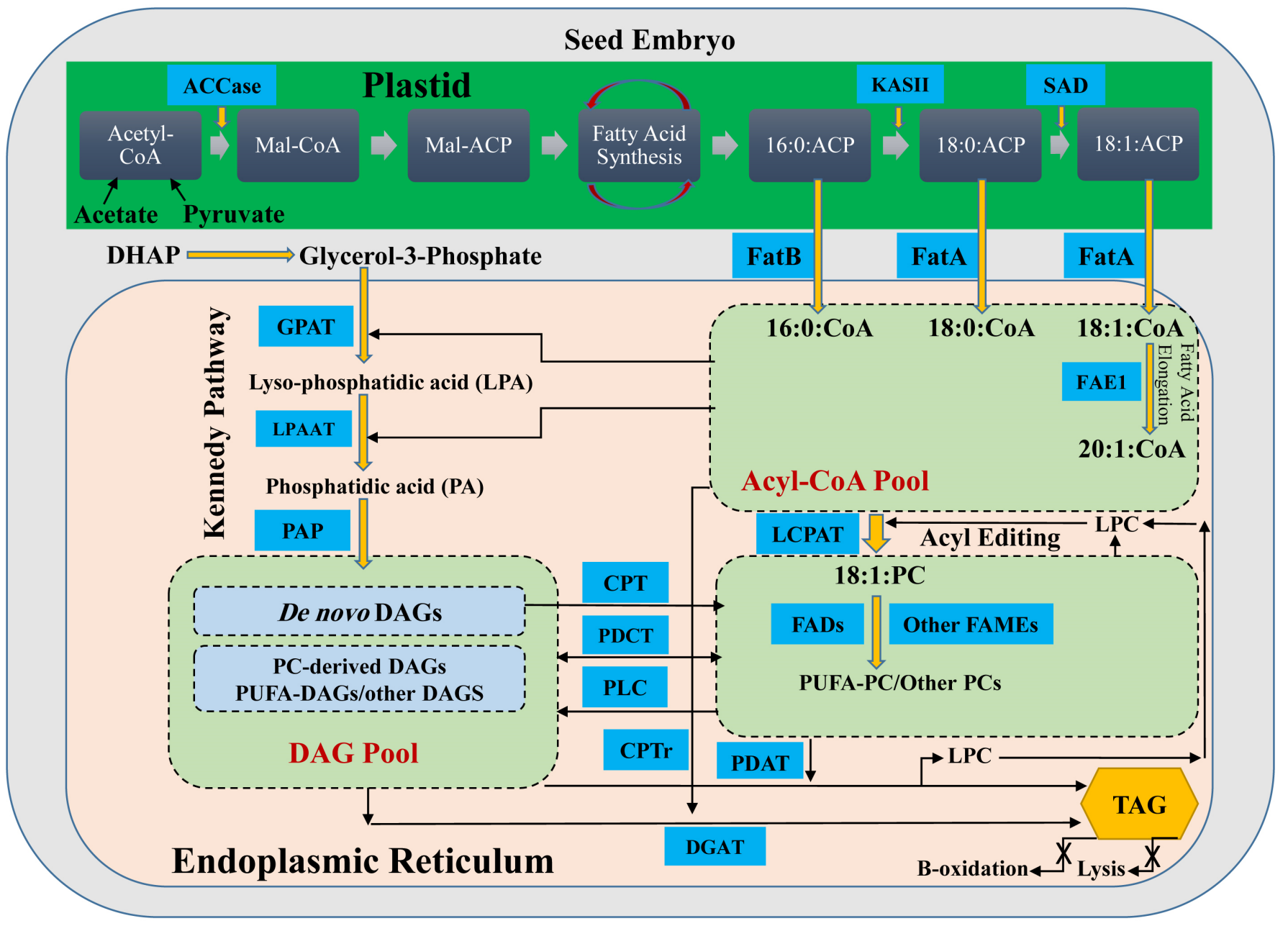

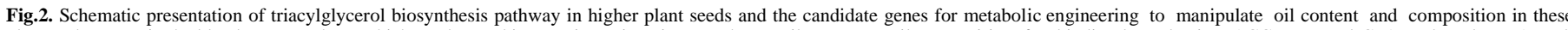

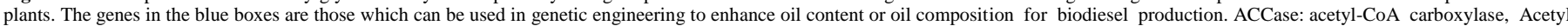

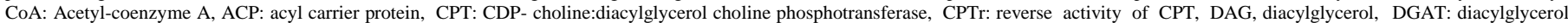

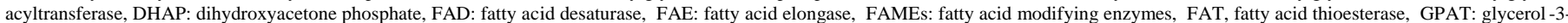

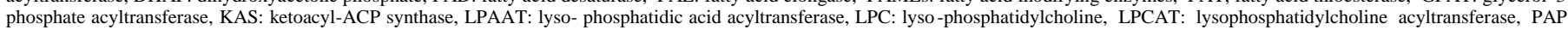

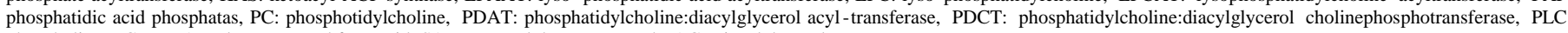
phospholipase C, PUFA: polyunsaturated fatty acid, SAD: stearoyl desaturase, and TAG: triacylglycerol.

2017). This gene has been transferred to other plants, including Camelina, maize, tobacco, potato, and rapeseed, and could significantly increase oil contents of these plants (Table 1) (Weselake et al., 2008; Zheng et al., 2008; Andrianov et al., 2010; Vanhercke et al., 2013; Kim et al., 2016; Chhikara et al., 2017; Liu et al., 2017). Moreover, expression of the genes encoding fatty acyl acyl carrier thioesterase A (FatA), glycerol-3-phosphate dehydrogenase $(G P D)$, and lysophosphatidyl-acyltransferases (LPAT) have improved the pathway of oil production, and thus, could be considered as key genes to improve oil contents in bioenergy plants (Singh et al., 2015; Liu et al., 2017). Each TAG commonly contain three fatty acid chains which are esterified to a glycerol backbone, and hence, the overexpression of the genes, such as that of glycerol-3-phosphate dehydrogenase, involved in glycerol-3-phosphate biosynthesis, could result in enhanced TAG biosynthesis (Akashi and Nanasato, 2018). Vigeolas et al. (2007) could significantly increase (up to 40\%) the oil content of canola seeds by overexpression of a yeast glycerol-3phosphate dehydrogenase gene (GPD1). Inhibition of TAG degradation in oil crops seeds is known as another strategy to enhance TAG abundance in lipid storage tissues. Sugar-dependent protein 1 triacylglycerol lipase (SDP1), which regulates the first step of TAG catabolism, could be a good target for metabolic engineering in oil crops (Akashi and Nanasato, 2018). Another method is the inhibition of TAG lysis and degradation. It has been previously confirmed that the gene SDP1 encodes a patatin-like acyl hydrolase domain (a specific lipase), which is involved in the first step of TAG degradation during seed germination, and is capable of associating with the surface of the oil bodies and other reported PTLs (Eastmond et al., 2006 and 2007). The RNA interference (RNAi) technology has also been used to express a homologue of the $S D P 1$ in oilseed rape (Brassica napus), which resulted in a significant reduction of SDP1 protein expression and subsequently, an increase in oil content (Kelly et al., 2013).

In addition to the genes involved in TAG biosynthesis (oil content), engineering other genes playing key roles in some agronomical traits, such as seed, fruit and leaf size, plant growth and biomass, as well as root architecture and vegetative/reproductive transition, have important effects on potentials of bioenergy plants as source of biodiesel production (Table 1) (Jakob et al., 2014; Akashi and Nanasato, 2018). The seed size has an important role in oil yield of Jatropha, and therefore, it has been taken into account as the main goal of breeding to enhance oil yields. Recently, a candidate gene (CYP78A98) with potentials for increasing seed size, has been identified in Jatropha. The expression of this gene in tobacco resulted in increased seed size and weight as well as protein and fatty acid contents (Tian et al., 2016). 
Table 1.

GM strategies and genes used to improve oil content and seed size in edible and nonedible crops.

\begin{tabular}{|c|c|c|c|c|c|}
\hline Target trait & Gene & Function & $\begin{array}{l}\text { GM } \\
\text { Strategy/Technology }\end{array}$ & Oil plants & Reference \\
\hline \multirow{5}{*}{$\begin{array}{l}\text { Improving } \\
\text { triacylglycerol (TAG) synthesis }\end{array}$} & Acetyl-CoA carboxylase (ACCase) & $\begin{array}{l}\text { Increases the Malonyl-CoA } \\
\text { utilization }\end{array}$ & Expression & Rapeseed & Roesler et al. (1997) \\
\hline & $\begin{array}{l}\text { Diacylglycerol acyltransferase } 1 \\
(D G A T 1)\end{array}$ & Conversion of DAG to TAG & Overexpression & $\begin{array}{l}\text { Camelina } \\
\text { Maize } \\
\text { Tobacco } \\
\text { Arabidopsis } \\
\text { Potato } \\
\text { Tobacco } \\
\text { Rapeseed }\end{array}$ & $\begin{array}{l}\text { Jako (2001); Weselake et al. } \\
\text { (2008); Zheng et al. (2008); } \\
\text { Andrianov et al. (2010); Vanhercke } \\
\text { et al. (2013); Kim et al. (2016); } \\
\text { Chhikara et al. (2017); Liu et al. } \\
\text { (2017) }\end{array}$ \\
\hline & $\begin{array}{l}\text { Glycerol-3-phosphate dehydrogenase } \\
\text { (GPDI) }\end{array}$ & $\begin{array}{l}\text { Catalyzes the acylation of G3P that } \\
\text { results in lysophosphatidic acid } \\
\text { (LPA) production }\end{array}$ & Overexpression & $\begin{array}{l}\text { Camelina } \\
\text { Soybean } \\
\text { Rapeseed }\end{array}$ & $\begin{array}{l}\text { Vigeolas and Geigenberger (2004); } \\
\text { Vigeolas et al. (2007); Chhikara et } \\
\text { al. (2017) }\end{array}$ \\
\hline & $\begin{array}{l}\text { Patatin-related phospholipase } \\
\text { (pPLAIII })\end{array}$ & $\begin{array}{l}\text { Hydrolyzing PC to free FAs and } \\
\text { LPC }\end{array}$ & Overexpression & Camelina & Li et al. (2015) \\
\hline & Yeast $s n-2$ acyltransferase gene & Conversion of DAG to TAG & Expression & Rapeseed & Zou et al. (1997) \\
\hline Inhibition of TAG degradation & $\begin{array}{l}\text { Sugar-dependent protein } 1 \\
\text { triacylglycerol lipase }(S D P I)\end{array}$ & $\begin{array}{l}\text { Regulates the first step of TAG } \\
\text { catabolism }\end{array}$ & Suppression/RNAi & $\begin{array}{l}\text { Rapeseed } \\
\text { Jatropha }\end{array}$ & $\begin{array}{l}\text { Kelly et al. (2013) } \\
\text { Kim et al. (2014) } \\
\text { Chua et al. (2017) }\end{array}$ \\
\hline Transcription factors & WRII & $\begin{array}{l}\text { A transcription factor of } \\
\text { APETALA2/ethylene-responsive } \\
\text { element binding (AP2/EREBP) }\end{array}$ & Expression & $\begin{array}{l}\text { Camelina } \\
\text { Arabidopsis } \\
\text { Tobacco }\end{array}$ & $\begin{array}{l}\text { An and Suh (2015) } \\
\text { Cernac and Benning (2004) } \\
\text { Ivarson et al. (2017) } \\
\text { Vanhercke et al. (2013) }\end{array}$ \\
\hline \multirow{7}{*}{$\begin{array}{l}\text { Improving morphological and } \\
\text { developmental traits }\end{array}$} & Auxin response factor 19 (JCARF19) & $\begin{array}{l}\text { Controls plant organ size and } \\
\text { increases seed size }\end{array}$ & Overexpression & $\begin{array}{l}\text { Jatropha } \\
\text { Arabidopsis }\end{array}$ & Sun et al. (2017) \\
\hline & $\begin{array}{l}\text { Zea maize leafy cotyledon1 (LEC1) } \\
\text { (ZmLEC1) }\end{array}$ & $\begin{array}{l}\text { A master regulator of embryo } \\
\text { development }\end{array}$ & Overexpression & $\begin{array}{l}\text { Camelina } \\
\text { Arabidopsis } \\
\text { Maize }\end{array}$ & $\begin{array}{l}\text { Zhu et al. (2018) } \\
\text { Shen et al. (2010) } \\
\text { Yu et al. (2014) }\end{array}$ \\
\hline & $\begin{array}{l}\text { Arabidopsis purple acid phosphatase } \\
2 \text { (AtPAP2) }\end{array}$ & $\begin{array}{l}\text { Sucrose phosphate synthase (SPS) } \\
\text { activity and efficient sucrose } \\
\text { transport from leaves to sink }\end{array}$ & Expression & Camelina & Zhang et al. (2012) \\
\hline & $\begin{array}{l}\text { Arabidopsis G-protein c subunit } 3 \\
(A G G 3)\end{array}$ & $\begin{array}{l}\text { Heterotrimeric GTP-binding } \\
\text { protein (G-protein) }\end{array}$ & Overexpression & Camelina & Choudhury et al. (2014) \\
\hline & Flowering locus $\mathrm{T}\left(J_{c} F T\right)$ & Early flowering & Overexpression & Jatropha & Li et al. (2014) \\
\hline & $\begin{array}{l}\text { Glycolate dehydrogenase }(G D H) \text { or } \\
\text { glyoxylate carboligase }(G L C) \text {, and } \\
\text { tartonic semialdehyde reductase } \\
(T R S)\end{array}$ & $\begin{array}{l}\text { Photo-respiratory bypass bacterial } \\
\text { genes }\end{array}$ & Expression & Camelina & Price et al. (2008) \\
\hline & $\mathrm{CO}_{2} / \mathrm{HCO}$-transporter genes & Transporting $\mathrm{CO}_{2} / \mathrm{HCO}$ & Expression & Camelina & Dalal et al. (2015) \\
\hline
\end{tabular}

A suitable oil for biodiesel production should have a high oxidative stability, less polyunsaturated fatty acids, and low viscosity under low temperatures. Thus, high contents of monounsaturated fatty acids (oleic and palmitoleic acids) and low contents of polyunsaturated fatty acids (linoleic acid) are suitable for biodiesel production. For instance, 16- to 18 -carbon fatty acids ratio has a direct impact on the quality of biodiesel and on its combustion performance. Since the optimal FA composition of the raw oil used in the biodiesel production process is critical to achieve good acceptance by both customers and vehicle manufactures, thus, improvement of desirable physicochemical properties of oil by engineering of oil composition is also an important research target. Different GM methodologies have been used to enhance oil composition and quality in oil plants (Ciubota-Rosie et al., 2013; Sainger et al., 2017). This involves, 1) increase of oleic acid content by down regulation of either fatty acid desaturase 2 (FAD2), Acyl-ACP thioesterase $(F A T B)$, or fatty acid elongase 1 (FAE1) genes, 2) expression of the genes encoding medium chain fatty acids (MCFAs) by expression of FatB or suppression of KASII (ketoacyl-ACP synthase II), 3) production of omega-7 monounsaturated fatty acids by expression of plastidial desaturase with extraplastidial 16:0 $\Delta 9$ desaturases, and/or suppression of KASII elongase,4) production of hydroxylated fatty acids (HFAs), and 5) 
Table 2.

GM strategies and genes used to improve oil composition and quality in edible and nonedible crops.

\begin{tabular}{|c|c|c|c|c|c|}
\hline Target & Gene & Function & GM Strategy/Technology & Oil plants & Reference \\
\hline \multirow{3}{*}{$\begin{array}{l}\text { Increase of oleic acid } \\
\text { contents }\end{array}$} & Fatty acid desaturase (FAD2) & Fatty acid unsaturation & $\begin{array}{l}\text { Suppression (RNAi or } \\
\text { CRISPR-Cas9) }\end{array}$ & $\begin{array}{l}\text { Camelina } \\
\text { Jatropha } \\
\text { Rapeseed } \\
\text { Flax } \\
\text { Soybean }\end{array}$ & $\begin{array}{l}\text { Krohn and Fripp (2012); Qu et } \\
\text { al. (2012); Morineau et al. } \\
\text { (2017); Jiang et al. (2017); } \\
\text { Okuzaki et al. (2018); Chen et } \\
\text { al. (2015); Haun et al. (2014) }\end{array}$ \\
\hline & Fatty acid elongase $(F A E l)$ & $\begin{array}{l}\text { Involved in production of long } \\
\text { chain FAs }\end{array}$ & $\begin{array}{l}\text { Suppression (RNAi or } \\
\text { CRISPR-Cas9) }\end{array}$ & Camelina & $\begin{array}{l}\text { Krohn and Fripp (2012) } \\
\text { Ozseyhan et al. (2018) }\end{array}$ \\
\hline & Acyl-ACP thioesterase $(F A T B)$ & $\begin{array}{l}\text { FA chain termination during de } \\
\text { novo FA synthesis }\end{array}$ & $\begin{array}{l}\text { Suppression (RNAi or } \\
\text { CRISPR-Cas9) }\end{array}$ & $\begin{array}{l}\text { Camelina } \\
\text { Soybean } \\
\text { Jatropha }\end{array}$ & Buhr et al. (2002) \\
\hline $\begin{array}{l}\text { Production unusual } \\
\text { Acetyl-TAGs }\end{array}$ & $\begin{array}{l}\text { Euonymus alatus diacylglycerol } \\
\text { acetyltransferase (EaDAcT) }\end{array}$ & $\begin{array}{l}\text { Production of unusual acetyl-TAGs } \\
\text { to reduce kinematic viscosity and } \\
\text { melting points }\end{array}$ & Expression & $\begin{array}{l}\text { Camelina } \\
\text { Soybean } \\
\text { Arabidopsis }\end{array}$ & Liu et al. (2015) \\
\hline \multirow{3}{*}{$\begin{array}{l}\text { Production of medium } \\
\text { chain FAs (MCFAs) }\end{array}$} & $\begin{array}{l}\text { FatB genes (CpuFatB3, CvFatB1, } \\
\text { CpuFatB4) and coconut } L P A T\end{array}$ & $\begin{array}{l}\text { Involved in production of long } \\
\text { chain FAs }\end{array}$ & Expression/Co-expression & Camelina & Kim et al. (2015) \\
\hline & KASII ( $\beta$-ketoacyl-ACP synthase II) & $\begin{array}{l}\text { Determines the compositions of } \\
\text { C16:0 and C18:0 }\end{array}$ & Suppression/RNAi approach & Camelina & Kim et al. (2015) \\
\hline & UcFATBIand KASII & - & Expression/Suppression & Camelina & Hu et al. (2017) \\
\hline \multirow{3}{*}{$\begin{array}{l}\text { Production of } \omega-7 \\
\text { monounsaturated fatty } \\
\text { acids }\end{array}$} & $\begin{array}{l}\text { An engineered plastidial enzyme } \Delta 9 \text { - } \\
16: 0 \text {-ACP desaturase }\end{array}$ & & Expression & Camelina & Nguyen et al. (2010) \\
\hline & $\begin{array}{l}\text { Pastidial desaturase / extraplastidial } \\
\text { 16:0 } 9 \text { desaturases / KASII elongase }\end{array}$ & FA unsaturation & Expression and suppression & Camelina & Nguyen et al. (2010) \\
\hline & $\begin{array}{l}\text { A mutant } \Delta 9 \text {-acyl-ACP/ an acyl-CoA } \\
\text { desaturase / a second } \Delta 9-16: 0 \text {-ACP } \\
\text { desaturase / KASII and FatB }\end{array}$ & & $\begin{array}{l}\text { "six transgene strategy" / } \\
\text { Expression / RNAi suppression }\end{array}$ & Camelina & Nguyen et al. (2015) \\
\hline \multirow{3}{*}{$\begin{array}{l}\text { Production of } \\
\text { hydroxylated fatty } \\
\text { acids (HFAs) }\end{array}$} & Castor FA hydroxylase gene & & Expression & Camelina & Krohn and Fripp (2012) \\
\hline & $\begin{array}{l}\text { Ccastor oleate } \Delta 12 \text { hydroxylase gene } \\
\text { (RCFAH12) }\end{array}$ & $\begin{array}{l}\text { Production of hydroxylated fatty } \\
\text { acids (HFAs) }\end{array}$ & Expression & Camelina & Lu and Kang (2008) \\
\hline & $\begin{array}{l}\text { RcFAH and LfKCS3 from Physaria } \\
\text { fendleri (encoding a fatty acid } \\
\text { condensing enzyme) }\end{array}$ & & Co-expression & Camelina & Snapp et al. (2014) \\
\hline \multirow[t]{2}{*}{$\begin{array}{l}\text { Reduction of toxins } \\
\text { and inhibitors }\end{array}$} & Curcin precursor gene & $\begin{array}{l}\text { Curcin is a type I ribosomal } \\
\text { inhibiting protein- RIP and a } \\
\text { phytotoxin }\end{array}$ & Suppression & Jatropha & Patade et al. (2014) \\
\hline & JcCASA: casbene synthase gene & Encoding phorbol ester & Suppression & Jatropha & Li et al. (2016) \\
\hline
\end{tabular}

reduction of toxins and inhibitors such as curcin and phorbol ester in seeds and oil by suppression of such genes (Table 2).

Since oleic acid (C18:1) which is a monounsaturated acyl chain with high cetane value, low melting point, and high resistance to oxidation, thus, it is a preferred component in TAGs (Akashi and Nanasato, 2018). Suppression of $F A T B$ and $F A D 2$ genes in different oil crops using RNAi or CRISPR-Cas9 has reportedly resulted in a significant increase of oleic acid in seed oils (Buhr et al., 2002; Qu et al., 2012). Commonly, the length of fatty acid chains is determined by the plastidial fatty acid synthase enzymes (three $\beta$-ketoacyl-acyl carrier protein synthases (KASI, II, and III)). Recently, some putative KAS genes have been identified and cloned from Jatropha. Expression of such genes in Arabidopsis resulted in a significant increase of palmitic acid content as well as the 16- to 18-carbon fatty acids ratio (Yu et al., 2015; Xiong et al., 2017). It was shown that $J c K A S I-1$ and $J c K A S I-2$ exhibit partial functional redundancy and play a universal role in regulating fatty acid biosynthesis, growth, and development in plants. Other researches have confirmed that species-specific fatty acid desaturases (FAD2, FADX, FAH12, etc.), oleocins, and phospholipid:diacylglycerol acyl transferase (PDAT) proteins are involved in or regulating fatty acid compositions in seeds of Vernicia and Jatropha (Yang et al., 2016).
Enhancing tolerance to biotic (pest and diseases) and abiotic (drought, salinity, freezing, and heavy metals) stresses to improve yield productivity in oil plants is another strategy widely used (Table 3). Abiotic stresses such as water deficit, high salinity, high temperature, freezing, and heavy metals pollutions are recognized as the most important factors negatively affecting plant growth and crop productivity. Therefore, engineering oil plants to enhance tolerance to these abiotic stresses could have a tremendous potential to expand their cultivation zones to drought-, heat-, and/or salinity-affected marginal lands (Akashi and Nanasato, 2018). Different genes, such as fatty acid hydroxylase12 (FAH12) (van Erp et al. 2011), transcription factors (MYB96) (Lee et al., 2014), phosphopantetheine adenylyltransferase (PPAT), the subunit of the NF-Y transcription factor (NF-YB), and GSMT/DMT (Tsuchimoto et al., 2012) have been used to enhance drought tolerance in oil crops (Table 3).

The genes, such as those encoding transcription factors, involved in biotic and abiotic stress tolerance are known as other important genes affecting oil production in bioenergy plants (Eswaran et al., 2010). These genes include the flowering-time-related $D o f$ transcription factor gene (Yang et al., 2010), accA, accB1, accC and $a c c D$ genes encoding the subunits of heteromeric ACCase (Gu et al., 2011), stearoyl-acyl carrier 
Table 3.

GM strategies and genes used to improve biotic and abiotic stresses tolerance in edible and nonedible crops.

\begin{tabular}{|c|c|c|c|c|c|}
\hline Target & Gene & Function & GM Strategy/Technology & Oil plants & Reference \\
\hline \multirow{5}{*}{ Drought tolerance } & Camelina fatty acid hydroxylase (RcFAH12) & FA hydroxylase & Expression & Arabidopsis & van Erp et al. (2011) \\
\hline & Arabidopsis transcription factor $M Y B 96$ & Transcription factor & Overexpression & Camelina & Lee et al. (2014) \\
\hline & $\begin{array}{l}P P A T \text {; phosphopantetheine } \\
\text { adenylyltransferase }\end{array}$ & Catalyzes the CoA biosynthesis pathway & Overexpression & Jatropha & Tsuchimoto et al. (2012) \\
\hline & $\begin{array}{l}N F-Y B: \text { The subunit of the NF-Y } \\
\text { transcription factor }\end{array}$ & $\begin{array}{l}\text { The B subunit of the nuclear factor Y (NF- } \\
\text { YB) transcription factor }\end{array}$ & Overexpression & Jatropha & Tsuchimoto et al. (2012) \\
\hline & $G S M T / D M T$ genes & $\begin{array}{l}\text { Encoding enzymes catalyzing production of } \\
\text { compatible solute glycine betaine }\end{array}$ & Overexpression & Jatropha & Tsuchimoto et al. (2012) \\
\hline \multirow{4}{*}{ Salinity tolerance } & acdS: ACC deaminase & $\begin{array}{l}\text { 1-aminocyclopropane-1-carboxylate } \\
\text { deaminase }\end{array}$ & Expression & Camelina & Heydarian et al. (2016) \\
\hline & $\begin{array}{l}s b N h x l \text { : encoding vacuolar } \mathrm{Na}+\mathrm{H}+\text { antiporter } \\
\text { (NHX1) }\end{array}$ & $\begin{array}{l}\text { Sequestration of excess } \mathrm{Na}+\text { into the vacuole } \\
\text { and } \mathrm{Na}+\text { homeostasis and salinity }\end{array}$ & Expression & Jatropha & Jha et al. (2013) \\
\hline & $J c D R E B$, a putative AP2/EREBP domain & A-6 subgroup members of DREB subfamily & Over-expression & Arabidopsis & Tang et al. (2011) \\
\hline & $\begin{array}{l}\text { GmsSOS1, a putative plasma membrane } \\
\mathrm{Na}+/ \mathrm{H}+\text { antiporter gene }\end{array}$ & $\begin{array}{l}\text { Decrease of } \mathrm{Na}+\text { absorption in roots and } \\
\text { transportation in shoots }\end{array}$ & Expression & Arabidopsis & Nie et al. (2014) \\
\hline \multirow{2}{*}{ Freezing tolerance } & Transcription factor $J_{c} C B F 2$ & $\begin{array}{l}\text { A cold response transcription } \\
\text { factor in Jatropha }\end{array}$ & Expression & Arabidopsis & Wang et al. (2015) \\
\hline & $J_{C D R E B}$, a putative AP2/EREBP domain & A-6 subgroup members of DREB subfamily & Over-expression & Arabidopsis & Tang et al. (2011) \\
\hline $\begin{array}{l}\text { Heavy metals } \\
\text { tolerance }\end{array}$ & CsHMA3 & A heavy metal $\mathrm{P}_{1 \mathrm{~B}}$-ATPase & overexpression & Camelina & $\begin{array}{l}\text { Park et al. (2014) } \\
\text { Park et al. (2015) }\end{array}$ \\
\hline Pest resistance & $\begin{array}{l}\text { crylAb/lAc: Bacillus thuringiensis d- } \\
\text { endotoxin }\end{array}$ & $\begin{array}{l}\text { Toxic for lepidopteran pests/ tortrix moth } \\
\text { (Archips micaceanus) }\end{array}$ & Expression & Jatropha & Gu et al. (2014) \\
\hline \multirow{5}{*}{ Disease resistance } & Cecropin Pl & Antimicrobial peptide & Expression & Camelina & Zakharchenko et. al. (2013) \\
\hline & $P R 1$ and $P R 3$ and defensin $(P D F 1.2)$ & Pathogenesis-related genes & Expression & Camelina & Nayanakantha et al. (2014) \\
\hline & $\begin{array}{l}\text { Defense regulatory gene PHYTOALEXIN } \\
\text { DEFICINT4 (PAD4) }\end{array}$ & $\begin{array}{l}\text { Broad-spectrum defense against different } \\
\text { pests }\end{array}$ & Overexpression & Soybean & Joshi et al. (2015) \\
\hline & Chitinase & $\begin{array}{l}\text { Involved in lysis of cell wall of plant } \\
\text { pathogens }\end{array}$ & Expression & Jatropha & Franco et al. (2016) \\
\hline & Hairpin dsRNA & $\begin{array}{l}\text { Homologous to five key genes of the } \\
\text { geminivirus Indian cassava mosaic virus }\end{array}$ & RNAi & Jatropha & Ye et al. (2014) \\
\hline \multirow{2}{*}{$\begin{array}{l}\text { Other abiotic } \\
\text { tolerance traits }\end{array}$} & $\begin{array}{l}\gamma \text {-glutamyl cyclotransferase gene }(G G C T 2) \\
\text { and Wrinkled } 1 ; \text { a transcription factor }\end{array}$ & $\begin{array}{l}\text { Oxidative stress tolerance via glutathione } \\
\text { homeostasis }\end{array}$ & Overexpression & Camelina & Ablordeppey (2014) \\
\hline & Isoprene synthase gene (PcISPS) & Isoprene emission & Expression & Camelina & Rossi and Xie (2014) \\
\hline
\end{tabular}

protein desaturase (SAD) (Tong et al., 2006), which have been previously isolated and characterized in J. curcas. Recently, a newly developed microarray system has been used to identify genes involved in Jatropha drought tolerance. As a result, about 1300 genes contributing to dehydration and/or recovery were characterized (Cartagena et al., 2015).

To enhance salinity tolerance, different genes encoding ACC deaminase (acdS), vacuolar $\mathrm{Na}+/ \mathrm{H}+$ antiporter (NHX1 and GmsSOS1), and AP2/EREBP domain have been expressed in some oil plants including Camelina, Jatropha, and Arabidopsis (Table 3) (Tang et al., 2011; Jha et al., 2013; Heydarian et al., 2016). Moreover, functionality of transcription factor $J C C B F 2$ (a cold response transcription factor) and $J C D R E B$ (a putative AP2/EREBP domain of DREB subfamily) derived from Jatropha, in improving freezing tolerance has been confirmed by expression in Arabidopsis (Tang et al., 2011; Wang et al., 2015). To enhance heavy metal tolerance, the CsHMA3 gene encoding a heavy metal $\mathrm{P}_{1 \mathrm{~B}}$-ATPase has been expressed in Camelina (Park et al., 2014 and 2015).

The Gram-positive aerobic bacterium Bacillus thuringiensis and its cry genes are known as the most important and efficient pest biological control agents widely used in plant protection strategies through biological control orgeneti engineeringprograms, respectively (Salehi Jouzani et al., 2005 and 2017). The B. thuringiensis d-endotoxin hybrid $c r y l A b / 1 A c$ genes which are toxic for lepidopteran pests was were to enhance Jatropha resistance to tortrix moth (Archips micaceanus) (Gu et al., 2014). In addition, some antifungal and antibacterial genes, including peptide cecropin $P 1$ (Zakharchenko et al., 2013), pathogenesis-related genes (PRI and PR3), and defensin (PDF1.2) (Nayanakantha et al., 2014), defense regulatory gene phytoalexin deficint 4 (PAD4) (Joshi et al., 2015), chitinase (Franco et al., 2016), and hairpin dsRNA (Ye et al., 2014) have been transferred to Camelina, soybean, and Jatropha. These successful histories confirm that genetic engineering could accelerate the improvement of oil crops for biodiesel production (Table 3). To show these potentials, recent advances in genetic engineering of Jatropha and Camelina will be discussed in the following section.

\section{Genetic engineering of Jatropha to improve oil production capacity}

Jatropha or physic nut, a wild plant belong to Euphorbiaceae, is a nonedible biofuel plant with high oil reserves. Jatropha has inherent drought tolerance, and therefore, has high potentials to be grown even in marginal lands. This provides a major advantage for Jatropha to avoid competition with food crops over agricultural lands (King et al., 2009; 
Sinha et al., 2016). This plant contains high amounts of qualified oil for biodiesel production. Moreover, Jatropha and its biomass/oil can be used as in soil improving, hedges, wind protection, soil erosion control, firewood, lamp fuel production, soap/paints/lubricants making, and also as a medicinal plant due to the production of different pharmacologically-important metabolites and substances (Kumar et al., 2015; Castro Gonzáles, 2016; Gudeta, 2016; Moniruzzaman et al., 2016; Cartagena, 2017). However, in spite of many advantages, such as rapid growth, easy propagation and harvesting, drought tolerance, reclaiming different types of land, pest resistance, short gestation periods, Jatropha has not been completely domesticated, and there has been slow progress in its breeding and use as biodiesel feedstock over the last several years due to some limitations and disadvantages associated with Jatropha. These include lack of high oil and biomass productive genotypes or commercial varieties, lack of genetic diversity, low seed yield due to low female to male flower ratio, high viscosity of the Jatropha oil, significant reduction of yield under insufficient irrigation and nutrients conditions, long waiting period (3-5 years) to achieve commercial productivity of the tree, presence of toxins such as curcin and toxic phorbol esters, and finally susceptibility to some pest and diseases as well as to frost and water logging. Therefore, the breeding objectives of Jatropha include improvements of seed yield, oil content, oil composition, reduction of toxicity, and enhanced tolerance to biotic and abiotic stresses (Brittaine et al., 2010; Divakara et al., 2010; Ceasar and Ignacimuthu, 2011; Edrisi et al., 2015; Moniruzzaman et al., 2016; Cartagena, 2017).

To overcome agronomical limitations of Jatropha, recently, many studies have been performed aimed at characterizing the genes involved in metabolic pathways in Jatropha, while some conventional breeding methods, based on phenotypic selection strategies, have also been used to increase the productivity of $J$. curcas, which resulted in new cultivars with improved oil yields. These studies have been well reviewed by Cartagena (2017), Moniruzzaman et al. (2016), and Montes et al. (2016). Although conventional breeding has shown significant positive effects in improving different traits, and resulted in the release of new varieties with higher yields and productivity, early maturation, resistance to pests and diseases, and tolerance to drought and cold, this procedure is laborious and time-consuming, especially for perennial plants such as Jatropha (Yue et al., 2013; Montes et al., 2016; Laviola et al., 2017).

In addition to the conventional breeding strategies, recently, omics-based breeding techniques have been widely used to improve agronomical traits of Jatropha to enhance economic and sustainable production of biodiesel. These include MAS-based and genomic (GS)-based selection using a diverse range of molecular tools, such as DNA markers, linkage, and QTL mapping, genomics (NGS), proteomics, transcriptomics, and metabolomics (Costa et al., 2010; King et al., 2011; Eswaran et al., 2012; Yue et al., 2013; Agarwal et al., 2014; Cartagena et al., 2014; Zhang et al., 2015). The whole genome sequence and linkage map of Jatropha have been reported several times during the last years. Such information is a very important component in molecular breeding and genetic improvement of this plant (Sato et al., 2011; Hirakawa et al., 2012; Wu et al., 2015) and could be used as a platform for performing genetic engineering procedures on Jatropha to enhance economic biodiesel production using this bioenergy plant.

\subsection{Tissue culture and transformation optimization}

It is clear that efficient application of genetic engineering for Jatropha improvement requires elite genotypes with optimized tissue and organ culture procedures as well as transformation protocols. Therefore, currently, the majority of research works in this field is focused on optimization of tissue culture and genetic engineering protocols and also on the identification of genes associated with important traits of Jatropha (Jaganath et al., 2014; Yang et al., 2016; Montes et al., 2016; Xiong et al., 2017). Since 1990, Agrobacteriummediated transformation is the most widely used method for transferring the genes into plant cells. Li et al. (2008) firstly used Agrobacterium-mediated transformation method for transformation of Jatropha. To improve transformation efficiency in Jatropha, different strategies such as different types of plant tissues (Kumar et al., 2010), modifying the infection process (Khemkladngoen et al., 2011; Jaganath et al., 2014), as well as the age of plant tissues and the tissue culture methods have been tested as critical factors.

Agrobacterium-mediated and microprojectile bombardment transformation have been developed for Jatropha. For instance, Agrobacteriuim-mediated cotyledon disc transformation (Li et al., 2008; Pan et al., 2010), Agrobacteriuim-mediated leaf explants transformation (Kumar et al., 2010),
Agrobacterium-mediated transformation using leaf and hypocotyl segments (Misra et al., 2012), Agrobacterium-mediated transformation using vacuum infiltration and vegetative in vivo cleft grafting method without the aid of tissue culture (Jaganath et al., 2014; Nanasato et al., 2015), and microprojectile bombardment using embryo axes (Purkayastha et al., 2010; Joshi et al., 2011) have been optimized for this purpose. In spite of such advances in the related protocols, tissue culture is still regarded as one of the major limitations in creating transgenic Jatropha plants (Cartagena, 2017). In vivo transformation has been efficiently performed in germinating Jatropha seeds (Patade et al., 2014) and plantlets (Jaganath et al., 2014). These methods included creating some wounds on the tissues prior to Agrobacterium infection. Moreover, a grafting method has also been developed to propagate transgenic Jatropha, which resulted in $100 \%$ genetic stability between mother and grafted plants (Jaganath et al., 2014). Furthermore, to reduce environmental and health risks of genetically modified (GM) Jatropha plants, some techniques, such as the creation of marker-free transgenic plants using the chemical inducible Creloxmediated site-specific recombination system, have been developed (Qu et al., 2012; Gu et al., 2014). This would reduce the biosafety issues associated with GM plants while it also would facilitate the acceptance of transgenic Jatropha plants by the public.

\subsection{Genetic engineering to enhance oil contents in Jatropha}

Engineering the genes attributed to yield parameters (fruit and seed size, oil contents, leaf size and numbers, early flowering, fast growing, etc.) is taken into account as the most important strategies to improve oil production in Jatropha. The genes encoding proteins involved in oil biosynthesis or metabolism as well as those involved in transcriptional control of these processes are important tools to unfold biotechnological enhancement of oil content and quality in Jatropha by direct genetic engineering (Ye et al., 2013; Moniruzzaman et al., 2016). Three key enzymes, i.e., DGAT, LPAT, and GPD, play important role in lipid biosynthesis pathway. However, other enzymes such as carboxyl transferase of the ACCase b subunit, the biotin carboxyl carrier protein of ACCase, acyl ACP thioesterase A, acyl-CoA binding protein, malonylCoA:ACP transacylase, betaketo acyl ACP synthase II, 3-keto acyl ACP reductase, beta-keto acyl ACP synthase I, acyl carrier protein $\omega$-3-fatty acid desaturase, $\omega$-6-fatty acid desaturase, and long chain acyl-CoA synthetase are also involved in lipid biosynthesis pathways in Jatropha, and could be promising candidates for oil yield and oil composition engineering (Natarajan et al., 2010; Moniruzzaman et al., 2016).

In an investigation, the gene encoding diacylglycerol acyltransferase (JcDGAT1), a key enzyme contributing to fatty acids biosynthesis pathway, was isolated from Jatropha seeds and was transferred to Arabidopsis. The transgenic Arabidopsis plants showed a gradual increase in total oil content from early seed development to their maturation (up by $30-41 \%$ ) without any phenotypic changes (Misra et al., 2013). The DGAT1 gene has also been transferred to many plants, including Camelina, maize, tobacco, potato, and rapeseed, reportedly leading to significant increases in the oil contents of these plants (Weselake et al., 2008; Zheng et al., 2008; Andrianov et al., 2010; Vanhercke et al., 2013; Kim et al., 2016; Chhikara et al., 2017; Liu et al., 2017). Hence, the overexpression of such gene could increase oil content in Jatropha as well. Early flowering is a preferred trait for Jatropha as a biodiesel feedstock. The flowering locus T (FT) gene is one of the central factors playing a crucial role in the transition from vegetative phase to flowering. Overexpression of a homolog gene $J c F T$ in GM Jatropha resulted in a significant early flowering phenotype ( $\mathrm{Li}$ et al., 2014). Moreover, it has been shown that the suppression of SDP1 gene resulted in a significant increased oil content in rapeseeds (Kelly et al., 2013). In a study, Kim et al. (2014) generated JCSDP1 deficiency in transgenic Jatropha using the RNAi technology, which resulted in 13 to $30 \%$ higher total seed storage lipid and $7 \%$ compensatory decrease in protein content (Kim et al., 2014).

Seed size is a key trait for enhancing oil yield in Jatropha, thus, increasing seed size is an opportunity to increase the amount of oil storage capacity. Sun et al. (2017) showed that auxin response factor 19 (JcARF19) is an effective factor in increasing seed size in J. curcas. They claimed that the overexpression of 19 (JCARF19) in two plants, i.e., A. thaliana and $J$. curcas, led to improved seed size. In addition to increasing oil content in 
seeds, increasing the number of female flowers and consequently, the number of fruits in Jatropha, has been regarded as a solution to increase oil yield in this bioenergy plant. For instance, Pan et al. (2016) by treating inflorescence meristems of Jatropha could increase fruit number using thidiazuron.

\subsection{Genetic engineering for improving oil composition in Jatropha}

FAD2 is a key enzyme contributing to linoleic acid biosynthesis in plants. Qu et al. (2012) could identify three putative fatty acid desaturase genes in Jatropha (JCFAD2s) by using genome wide analysis. Down regulation of $J_{C F A D 2-1}$ gene through the expression of its homologue in Jatropha using the RNAi technology resulted in significant increases in oleic acid contents (> $78 \%)$ and reduction of the polyunsaturated fatty acids contents $(<3 \%)$ compared with the wild type plants. Another gene involved in the determination of oil composition in Jatropha is acyl-acyl carrier protein (ACP) thioesterase named JCFATB1. This gene increases saturated fatty acids content and in particular, palmitate in plant oils (Wu et al., 2009). Therefore, suppression of this gene would enhance the production of unsaturated fatty acids such as oleic acid.

\subsection{Genetic engineering for reduction of toxic metabolites in Jatropha}

One of the most important drawbacks of Jatropha for biofuel production is the presence of some toxic metabolites such as phorbol esters and curcins (a type 1 ribosome inactivating protein) in the seeds. These metabolites are known as skin-irritating and cancer-promoting toxins and reduce the nutritional and commercial value of seeds and oil obtained from this plant (Gu et al., 2015). Thus, reduction of such toxins would significantly enhance oil quality of Jatropha. Some research works have successfully used the RNAi technology to reduce curcins in Jatropha. Suppression of this gene could reduce the curcin up to $98 \%$ (Patade et al., 2014; Gu et al., 2015). The cDNA of the gene encoding curcin, i.e., curcin 2 was obtained from $J$. curcas leaves (Tong et al., 2007). Recently, three curcin genes have been isolated and characterized from $J$. curcas MD44 (Wu et al., 2017). In addition, a specific RNAi technology was used to down-regulate a phorbol ester gene (JCCASA: casbene synthase gene). This suppression strategy could effectively reduce the gene expression and resulted in a final $85 \%$ reduction of phorbol esters level in seeds ( $\mathrm{Li}$ et al., 2016).

\subsection{Genetic engineering to enhance biotic and abiotic stress tolerance in Jatropha}

Identification, cloning, and transformation of the genes attributed to Jatropha tolerance to biotic (diseases and pests) as well as to abiotic stresses (e.g., drought, salinity, and cold) is of importance in breeding programs of Jatropha. In light of that, other transgenic Jatropha have been developed for other agronomic traits, such as salinity tolerance (Jha et al., 2013), drought tolerance (Tsuchimoto et al., 2012), pest resistance using B. thuringiensis cry genes (Gu et al., 2014), fungal disease resistance (Franco et al., 2016), and geminivirus resistance (Ye et al., 2014).

\subsubsection{Enhancing biotic stresses tolerance}

Jatropha due to the production of some insecticidal and toxic metabolites in all its tissues, is not susceptible to the majority of pests and pathogens, however, it has been shown that various fungi, viruses, insects, etc. causing serious damages of economic significance could attack this plant. These pests include 35 fungal species, 4 viral and 4 bacterial pathogens, 6 nematodes, and about 60 insect species (Anitha and Varaprasad, 2012). Thus, performing Jatropha breeding programs for pest and diseases resistance is of importance as well. The Archips micaceanus (Walker), a moth of the family Tortricidae, is known as one of the most important pests of Jatropha. In 2014, a hybrid of crylAb and crylAc genes encoding $\delta$-endotoxin proteins derived from the bacterium $B$. thuringiensis which confers resistance to lepidopteran insects, was expressed in Jatropha using Agrobacterium-mediated transformation and a chemically regulated, Cre/loxP-mediated DNA recombination system (Gu et al., 2014). It was reported that the insecticidal bioassays of the GM line of Jatropha resulted in $80-100 \%$ mortality of larvae of A. micaceanus four days after infestation.

Recently, to enhance disease resistance in Jatropha, Franco et al. (2016) expressed a chitinase gene from the fungus Trichoderma viride into the genome of a Jatropha superior genotype by inoculating leaf explants with Agrobacterium-mediated transformation. The results reported could be a start point for breeding programs concerning fungal disease resistance in Jatropha.

\subsubsection{Enhancing abiotic stresses tolerance}

Although Jatropha is known as a drought tolerant plant growing in semiarid lands unsuitable for food crops, however, its oil productivity is not economic under such stress conditions at the present time. Thus, enhancing drought tolerance is of significance toward commercialization of this plant as bioenergy plant, and it could contribute to improved oil productivity of Jatropha even in semi-arid lands. In an investigation, three kinds of drought tolerance transgenic Jatropha plants were generated by Tsuchimoto et al. (2012). The GM plants overexpressed the PPAT gene encoding the phosphopantetheine adenylyltransferase (catalyzing the CoA biosynthetic pathway); or the $N F-Y B$ gene encoding a subunit of the NF-Y transcription factor or two GSMT and DMT genes encoding osmolyte betaine synthesizing enzymes, including glycine sarcosine dimethylglycine methyltransferase and dimethylglycine Nmethyltransferase, respectively (Tsuchimoto et al., 2012).

Salinity is another stress adversely affecting the growth and yield of Jatropha. Salt tolerance in plants mainly depends on different physiological, biochemical, and molecular adaptations. It is well known that antiporters $\mathrm{Na}+\mathrm{H}+$ are important factors involved in plant salt tolerance. They help plants to maintain $\mathrm{Na}+$ homeostasis in the cytosol. Ion homeostasis is commonly performed either by sequestration of excess sodium into the vacuoles via vacuolar $\mathrm{Na}+\mathrm{H}+$ antiporters $(\mathrm{NHX} 1)$ or by active exclusion through $\mathrm{Na}+\mathrm{H}+$ antiporters (SOS1) located on the plasma membrane (Apse et al., 1999; Shi et al., 2000). The $s b N h x 1$ gene was previously isolated from an extreme halophyte, Salicornia brachiate. The gene was expressed in Jatropha to enhance salinity tolerance and the resultant GM Jatropha lines showed tolerance to $200 \mathrm{mM} \mathrm{NaCl}$ in the growth media (Jha et al., 2013).

\section{Genetic engineering of Camelina to improve oil production}

C. sativa (L.) (gold of pleasure or false flax) is known as a new emerging oilseed crop with some advantages such as less water, pesticide, and fertilizer requirements compared with the other traditional oilseed crops. Camelina is drought and cold tolerant, and therefore, can be used as a rotational crop with winter wheat (Ciubota-Rosie et al., 2013). Camelina biodiesel has less life cycle energy and less emissions compared with diese fuel, and also in the view of land use change emissions, Camelina biodiesel has higher performance compared with that of traditional biodiesel crops (Krohn and Fripp, 2012). However, Camelina oil is faced with some disadvantages, such as presence of high amounts (> 90\%) of long-chain $(\mathrm{C} 18-\mathrm{C} 22)$ and unsaturated FAs, which is undesirable for biodiesel and jet fuel production, as it could negatively affect biodiesel properties such as cetane number, iodine value, and oxidation stability (Hu et al., 2017). Other disadvantages are the atmospheric equivalent temperature (AET, 90\% recovered) and the polyunsaturated ( $\mathrm{P} 4$ double bonds) methyl ester content Therefore, one of the most important strategies in genetic engineering of Camelina is aimed at significantly decreasing its high degree of unsaturation and the molecular weight of the oil (Ciubota-Rosie et al., 2013). In addition to FA composition, other breeding targets for Camelina include increasing grain yield and oil content to make the plant more competitive to the other well-established oilseeds (Vollmann and Eynck, 2015). However, as Camelina has a remarkably undifferentiated hexaploid genome, all proteins and enzymes could be encoded by up to three similar gene homologues making modifying endogenous metabolic fluxes more difficult. For instance, diacylglycerol acyltransferase 1 (CsDGATI), microsomal oleate desaturases (CsFAD2), and elongase (CsFAE1) genes have three similar copies, which are expressed in developing seeds. Fortunately, it has been confirmed that the RNAi yechnology as well as the newly developed CRISPR/Cas9 genome editing technologies have tremendous potentials for silencing of target genes, such as all three homeologues of FAD2 in Camelina genome (Krohn and Fripp, 2012 Bansal and Durrett, 2016; Morineau et al., 2017). Moreover, GM Camelina has a low environmental biosafety risks due to its low outcrossing rate, no 
intercrossing with other species, and weak weed potential. These collectively mark this plant as a suitable platform for genetic engineering programs to enhance its feasibility for biodiesel production (Nayanakantha et al., 2014; Vollmann and Eynck, 2015).

\subsection{Tissue culture optimization for Camelina}

Different in vitro culture protocols have been tested and evaluated for organogenesis or somatic embryogenesis of Camelina. These protocols have been mainly focused on shoot organogenesis and regeneration using cotyledon with petiole, hypocotyl segment and leaf explants (Yemets et al., 2013), microspore culture (Ferrie and Bethune, 2011), and somatic hybridization (Narasimhulu et al., 1994). It has been confirmed that Camelina can be efficiently transformed by Agrobacterium-mediated floral-dip methods, and a variety of selectable markers (e.g., seed fluorescence and resistance to specific herbicides or antibiotics) can be easily used to identify Camelina transgenic seeds (Liu et al., 2012; Bansal and Durrett, 2016).

\subsection{Improving seed size and oil content in Camelina}

Different genetic engineering studies have been performed on Camelina to enhance oil yield, oil composition, and abiotic stress tolerance. One drawback associated with the application of Camelina as feedstock for biodiesel production is low oil contents of the seeds, so one of the most important GM strategies is to increase seed oil yields. The enzyme encoded by the gene $D G A T 1$ has been identified as one of the most key factors involved in the plant oil biosynthesis pathways. Kim et al. (2016) identified and cloned three DGATI genes (i.e., CsDGAT1A, CsDGAT1B, and CsDGAT1C) from developing Camelina seeds. Overexpression of CsDGAT1B in Camelina resulted in a $24 \%$ increase in total seed oils as well as larger embryonic cells and a greater number of cells compared with the wild type (Kim et al., 2016). Recently, DGAT1 and a yeast cytosolic GPD1 genes have been co-expressed in Camelina under the control of seed-specific promoters. This co-expression resulted in up to $13 \%$ higher seed oil content and up to $52 \%$ increase in seed mass compared with the wild-type plants. The oil harvest index for the GM lines was almost two folds higher than the wild type (Chhikara et al., 2017). In another study, the castor fatty acid hydroxylase gene was transferred to Camelina through Agrobacterium-mediated transformation with a vacuum infiltration procedure to enhance hydroxyl fatty acid synthesis in the plant. The transgenic seeds showed the expression of new castor fatty acid hydroxylase (Krohn and Fripp, 2012).

Camelina has small seeds, thus increasing seed size is of importance to improve oil content. Enhancing photosynthesis efficiency and increasing the carbon flux from photosynthesis into TAG biosynthesis may increase plant growth, seed characteristics, and oil content (Enjalbert et al., 2013; Sainger et al., 2017). For instance, it has been shown that overexpression of the Arabidopsis purple acid phosphatase 2 (AtPAP2) in Camelina resulted in early flowering, rapid growth, and enhanced seed yield and size (Zhang et al., 2012). Heterotrimeric GTP-binding protein (G-protein) is very important for plant growth and development. Therefore, enhancing the expression of such protein may improve seed size and plant growth. Overexpression of Arabidopsis Gprotein c subunit 3 (AGG3) in Camelina reportedly resulted in significant increases of photosynthesis efficiency, seed and oil production, stress tolerance, fruit number, 1000-seed weight, and seed yield (Choudhury et al., 2014). The leafy cotyledon 1 (LEC1) is another key protein which regulates embryo development and enhances the expression of genes involved in FA biosynthesis. Recently, the ZmLECl gene, isolated from maize, was overexpressed in A. thaliana and C. sativa, and could significantly increase (> $20 \%$ ) the oil content in mature seeds of both plants (Zhu et al., 2018).

Phosphatidycholine (PC) turnover has a crucial function in the process of TAGs biosynthesis. Enhancing the expression of phospholipases involved in the conversion of PC to free FAs may enhance TAG production. For instance, the overexpression of $p P L A I I I \delta$ (a patatin-related phospholipase, hydrolyzing PC to free FAs and lyso-phosphatidylcholine (LPC)) in Camelina has increased seed oil content (Zhang et al., 2012). Moreover, other strategies, such as expression of different photo-respiratory bypass bacterial genes glycolate dehydrogenase $(G D H)$ or glyoxylate carboligase $(G L C)$, as well as tartonic semialdehyde reductase (TRS) genes in Camelina chloroplast has reportedly resulted in reduction of the photo-respiratory carbon loss and the crop cycle (by 1-2 weeks), and increased the photosynthesis efficiency, plant growth, seed yield (50-72\%), and nitrogen use efficiency (15\%) (Dalal et al., 2015 Sainger et al., 2017). In addition, the expression of cyanobacterial $\mathrm{CO}_{2} / \mathrm{HCO}$-transporters in Camelina could increase $\mathrm{CO}_{2}$ assimilation in leaf tissues and seed yields by 20-40 \% (Price et al., 2008). Over-expression of Arabidopsis WRINKLED 1 (AtWRII), a transcription factor of APETALA2/ethylene-responsive element binding (AP2/EREBP) in Camelina was another strategy, which was used to improve seed size and oil content. The resultant GM lines showed a $14 \%$ increase in seed mass and total seed oil content (An and Suh, 2015).

\subsection{Improving oil composition in Camelina seeds}

It is well documented that the degree of saturation and length of FAs chain in oils could significantly affect fuel properties, such as viscosity, combustion quality, ignition delay, and oxidative stability. Therefore, improvement of oil composition in Camelina for finer biodiesel is of importance. High contents of oleic acid increases biodiesel quality through its greater oxidative stability, low cetane number, and better cold-flow properties, hence, high oleic content lines of Camelina are of huge interest for the biofuel industry (Durrett et al., 2008). New gene silencing techniques such as RNAi and CRISPR-Cas 9 genome editing have been applied and optimized for Camelina. RNAi suppression of FAD2 and FAE1 genes have resulted in reduced concentrations of linoleic, linolenic, and eicosaenoic acids, whereas oleic acid was accumulated at levels as high as 66\% (Krohn and Fripp, 2012). Recently, targeted mutagenesis for three different delta-12-desaturase (FAD2) genes was achieved by CRISPR-Cas 9 gene editing in Camelina. These mutations resulted in reduced levels of polyunsaturated fatty acids and increased accumulation of oleic acid in the oil. Genetic analysis of the mutants during four generations showed the heritability of single, double, and triple mutations in the three isologous $C s F A D 2$ genes. Moreover, combinatorial association of different alleles for the three $F A D 2$ loci enhanced oleic acid accumulation in the oil of the mutant Camelina lines from 10 to 62\% (Morineau et al., 2017). In another study, the CRISPR/Cas 9 was used to target the FAD2 gene in A. thaliana and $C$. sativa to enhance seed oil composition. As a result, transgenic Camelina seeds showed a significant increase of oleic acid content (16-50\% of the fatty acid composition) and significant decreases in less desirable polyunsaturated fatty acids content, i.e., linoleic acid (a decrease from $\sim 16 \%$ to $<4 \%$ ) and linolenic acid (a decrease from $\sim 35 \%$ to $<10 \%)$. These traits were stable up to T3 and T4 generation Camelina seeds (Jiang et al., 2017).

The second strategy to optimize oil composition would be the expression of genes involved in the biosynthesis of medium-chain FAs (MCFAs, 8:0 14:0). These kinds of FAs are commonly used as Jet A fuel (Kallio et al., 2014). In a study, three FatB genes (i.e., CpuFatB3, CvFatB1, and CpuFatB4) involved in high accumulation of MCFAs in Cuphea seeds were identified. The expression of the FatB genes and coconut LPAT in Camelina in single or co-expression form led to accumulation of capric acid (10:0), 16:0, myristic acid (14:0), lauric acid (12:0), or 14:0 in Camelina seeds. Moreover, RNAi approach has been used for seed specific suppression of Camelina KASII which resulted in the reduction of 12:0 bu enhanced palmitic acid (16:0) and MCFA contents in seeds to mimic Jet A fuel composition (Kim et al., 2015). In another study, simultaneous expression of a 12:0-acyl-carrier thioesterase gene (UcFATB1) from California bay (Umbellularia californica Nutt.) and suppression of the Camelina KASII genes by RNAi constructs led to enhanced accumulation of three medium-chain saturated FAs, including laurate (C12:0), myristate (C14:0), and palmitate (C16:0) in Camelina seed oils (Hu et al., 2017).

It has been confirmed that $\omega-7$ unsaturated FAs, such as palmitoleic acid $(16: 1 \Delta 9)$ and vaccenic acid $(18: 1 \Delta 11)$, are suitable for biodiesel production due to their better cold-flow properties, high oxidative stability, as well as reduced $\mathrm{NO}_{\mathrm{x}}$ emissions and ignition quality. Expression of a plastidial enzyme $\Delta 9-16: 0-\mathrm{ACP}$ desaturase in Camelina seeds increased $\omega-7$ unsaturated FAs contents by $2-14 \%$. Co-expression of this plastidial desaturase with extraplastidial 16:0 9 desaturases and suppression of KASII elongase resulted in $71 \%$ further increase of such FAs (Nguyen et al., 2010). In a different investigation, Nguyen et al. (2015) developed a named "six transgene strategy" through which they performed the coexpression of a mutant $\Delta 9$-acyl-ACP, an acyl-CoA desaturase, a second $\Delta$ 9-16:0-ACP desaturase transgene, as well as RNAi suppression of KASII 
and FatB in Camelina. This GM strategy could significantly increase the amount of $\omega-7$ unsaturated FAs to $\sim 60-65 \%$ of the total FAs, and significantly decreased the amount of total saturated FAs contents by 2-3 folds (Nguyen et al., 2015).

HFAs are rare FAs, commonly seen in castor and lesquerella oil, and are used for production of polyesters, biodiesel, and lubricants. The seed specific expression of castor oleate $\Delta 12$ hydroxylase gene (RcFAH12), involved in the biosynthesis of 18:1-OH, increased the accumulation of HFAs in the Camelina seed oil by 15\% (Lu and Kang, 2008). In a different study, RcFAH and LfKCS3 from Physaria fendleri (encoding a FA condensing enzyme) were co-expressed in Camelina, which resulted in elongated HFAs such as lesquerolic acid accumulation (8\%) with normal oil content and seed viability (Snapp et al., 2014).

\subsection{Improving biotic and abiotic tolerance in Camelina}

Camelina commonly shows high resistance to pests and pathogens, however, some fungi, such as Plasmodiophora brassicae, Albugo candida, Erwinia carotovora, Fusarium sporotrichioides, Alternaria brassicae and Candidatus phytoplasma asteris, as well as some insect pests (aphids) could reportedly cause damages to this plant (Sainger et al., 2017). In light of that, GM Camelina varieties expressing some antimicrobial proteins, including cecropin P1 (Zakharchenko et al., 2013), defensin, and pathogenesis-related genes (PR1 and PR3) (Nayanakantha et al., 2014), have been successfully created to enhance resistance to E. carotovora, F. sporotrichioides, and A. brassicae.

Camelina is also known as a drought adaptive plant and this attribute could cause reductions in its yield productivity during abiotic stresses. Lee et al. (2014) transferred a transcription factor gene MYB96 to Camelina. The results confirmed that the expression of this gene improved the expression of several Camelina cuticular wax biosynthetic genes by two to seven folds, and consequently increased accumulation of cuticular wax (Lee et al., 2014). The gene encoding 1-aminocyclopropane-1-carboxylate deaminase (acdS: ACC deaminase) which enhances abiotic tolerance in plants by reducing stress ethylene, was transferred to Camelina. The GM Camelina lines expressing acdS, showed higher root length and weight, seed production, as well as seed quality and seed oil content under salt stress compared with the wild type (Heydarian et al., 2016).

Isoprene has the ability to extinguish reactive oxygen species produced in plants during different abiotic stresses, thus enhancing the concentration of isoprene in plants especially during abiotic stresses could be promising in inducing tolerance. It has been well documented that plants with high isoprene emissions are naturally tolerant to some abiotic stresses, such as high temperatures, high light intensities, and high $\mathrm{O}_{3}$ concentrations. To enhance such abilities in the plants lacking isoprene emission, such as Camelina, it is possible to transfer isoprene synthase gene (PcISPS) to the plant genome (Rossi and Xie, 2014). Moreover, the citrus limonene synthase gene $(l s)$, geranyl diphosphate synthase $(G D P)$, monoterpene synthase $(L S)$, farnesyl diphosphate synthase $(F D S)$, and sesquiterpene synthase $(C D N S)$ have been transferred to the Camelina genome in the single or in co-expression forms, and resulted in more adaptation to abiotic stresses in Camelina (Augustin et al., 2015; Borghi and Xie, 2016). It has been also shown that the overexpression of $\gamma$-glutamyl cyclotransferase gene (GGCT2) in Camelina could improve oxidative stress tolerance in this plant. This protein is a part of $\gamma$-glutamyl cycle involved in the synthesis and degradation of glutathione and recycling of amino acids (Ablordeppey, 2014).

It has been reported that Camelina genome contains a heavy metal P1BATPase gene ( $\mathrm{mma3}$ ), making this plant more tolerant to heavy metals (such as $\mathrm{Cd}, \mathrm{Pb}$, and $\mathrm{Co}$ ), and more capable of accumulating heavy metals in shoots compared with rapeseed for instance (Park et al., 2014 and 2015; Sainger et al., 2017). Thus, this plant could be considered as promising candidate for phytoremediation purposes as well. Overall, the overexpression of CsHMA3 in transgenic Camelina plants improved many traits, including heavy metals tolerance, plant growth, seed yield, and total FAs content compared with the wild type plants under heavy metal stresses. It was shown that such improvements were ascribed to significant decreases of reactive oxygen species (ROS) and transporting heavy metals to vacuoles (Park et al., 2014 and 2015; Sainger et al., 2017).

\section{Challenges in genetic engineering of oil plants for biodiesel production}

Currently, the majority of the commercial production of biodiesel is dependent on oils derived from palm, soybean, and rapeseed by conventional methods. Changing the direction of biodiesel production from food crops to nonedible plants requires significant improvements in oil yield and quality of these plants as well as in their tolerance to biotic and abiotic stresses. As discussed throughout the present article, biotechnological interventions and genetic engineering approaches have shown great potentials to achieve these goals. However, the application of such technologies in oil plants is at their starting points, and there is no commercial oil plant with enhanced oil content or composition yet; there are laboratory and pilot scale samples though. Moreover, it is also necessary to thoroughly evaluate the potentials of genetic engineering technology in improving several other attributes of oil plants, i.e., environment adaptation, production cost, and economic feasibility in field scale. Lack of the presence of superior genotypes as a base for genetic engineering especially for nonedible plants such as Jatropha is known as one of the most important drawbacks in pursuing this path.

Developing high throughput tissue culture and transformation protocols for oil plants is also very important to produce a large number of primary GM lines. This is very critical for especially woody perennial trees. Mos of the GM oil crops have been evaluated at laboratory or greenhouse levels, and it is not clear that their response under field conditions are yet to be looked into. It should also be noted that genetic engineering methods might sometimes seem technically successful but would lead to commercial failures at large-scale production. Identification and characterization of major genes involved in TAG biosynthesis pathway as well as in adaptation to biotic and abiotic stresses are also of grave importance. In addition, it is necessary to carry out gene pyramiding programs to collect different agronomical traits in single superior genotypes of oil plants. This would help breeders to accelerate achieving superior genotypes suitable for commercial biodiesel production. Another challenge would be the biosafety issues related to GM oil plants, necessitating performing environmental and health risk assessments for such plants before commercial release. This would include evaluation of GM plants risks related to gene flow and potential negative effects on non-target organisms as well as the risks of potential negative effects on human and animal health.

\section{Concluding remarks}

During the last decades, significant developments have been reported on the technological aspects of genetic engineering of emerging oil plants with high potentials for biodiesel production. Recent revolutionary developments in NGS and other molecular biology technologies have provided excellent opportunities to accelerate identification and characterization of major genes involved in TAG biosynthesis and environmental adaptation of oil plants as source of bioenergy. These advances have provided very useful background for breeding programs to enhance oil contents, oil composition and quality, to reduce toxic metabolites, as well as to improve tolerance to biotic and abiotic stresses in different oil plants. The most of genetic engineering programs has been dedicated to expression, overexpression, or suppression of the major genes affecting oil yield, oil quality, and tolerance to biotic and abiotic stresses in bioenergy crops. Among these genes, DGAT and FAD genes have been widely used as major genes to enhance oil content and oil composition for biodiesel production in different oil plants, such as Jatropha, Camelina, soybean, rapeseed, Arabidopsis, etc. Some successful GM verities with enhanced oil contents, oil composition, and tolerant to biotic and abiotic stresses have been achieved. However, most of such GM plants have been evaluated at lab or greenhouse levels. Performing field trials to evaluate the efficiency and productivity of such GM biodiesel crops while also looking into their biosafety aspects are of importance in pursuing the commercialization of such plants for biodiesel production. Moreover, in the next phases, exploring other major genes with potentials for further improvements in oil content/quality and tolerance to biotic and abiotic stresses followed by pyramiding of such multiple transgenes conferring combined agronomical traits related to oil content and composition in a single plant would be expected. 


\section{Acknowledgements}

Authors gratefully extend their appreciation to all colleagues of Microbial Biotechnology Department of Agricultural Biotechnology Research Institute of Iran (ABRII) for their help during the preparation of this manuscript.

\section{References}

[1] Ablordeppey, K., 2014. Engineering Camelina sativa for biofuel production via increasing oil yield and tolerance to abiotic stresses. Master Degree Thesis, University of Massachusetts Amherst.

[2] Agarwal, P., Dabi, M., Agarwal, P.K., 2014. Molecular cloning and characterization of a group II WRKY transcription factor from Jatropha curcas, an important biofuel crop. DNA Cell Biol. 33(8), 503-513.

[3] Akashi, K., Nanasato, Y., 2018. Recent progress in the genetic engineering of biofuel crops. Biofuels: Greenhouse Gas Mitigation and Global Warming. Springer, New Delhi. 327-339.

[4] Alaba, P.A., Sani, Y.M., Daud, W.M.A.W., 2016. Efficient biodiesel production via solid superacid catalysis: a critical review on recent breakthrough. RSC Adv. 82, 78351-78368.

[5] An, D., Suh, M.C., 2015. Overexpression of Arabidopsis WRI1 enhanced seed mass and storage oil content in Camelina sativa. Plant Biotechnol. Rep. 9(3), 137-148.

[6] Andrianov, V., Borisjuk, N., Pogrebnyak, N., Brinker, A., Dixon, J., Spitsin, S., Flynn, J., Matyszczuk, P., Andryszak, K., Laurelli, M., Golovkin, M., Koprowski, H., 2010. Tobacco as a production platform for biofuel: overexpression of Arabidopsis DGAT and LEC2 genes increases accumulation and shifts the composition of lipids in green biomass. Plant Biotechnol. J. 8(3), 277-287.

[7] Anitha, K., Varaprasad, K.S., 2012. Jatropha pests and diseases: an overview. In Jatropha, challenges for a new energy crop . Springer, New York, NY. 175-218

[8] Apse, M.P., Aharon, G.S., Snedden, W.A., Blumwald, E., 1999. Salt tolerance conferred by over expression of a vacuolar $\mathrm{Na}^{+} / \mathrm{H}^{+}$antiport in Arabidopsis. Science. 285(5431), 1256-1258.

[9] Augustin, J.M., Higashi, Y., Feng, X., Kutchan, T.M., 2015. Production of mono- and sesquiterpenes in Camelina sativa oilseed. Planta. 242(3), 693-708.

[10] Axelsson, L., Franzén, M., Ostwald, M., Berndes, G., Lakshmi, G., Ravindranath, N.H., 2012. Perspective: Jatropha cultivation in southern India: assessing farmers' experiences. Biofuels, Bioprod. Biorefin. 6, 246-256

[11] Bansal, S., Durrett, T.P., 2016. Camelina sativa: an ideal platform for the metabolic engineering and field production of industrial lipids. Biochimie. 120, 9-16.

[12] Bates, P.D., Browse, J., 2012. The significance of different diacylgycerol synthesis pathways on plant oil composition and bioengineering. Front. Plant Sci. 3, 1-11.

[13] Bates, P.D., Stymne, S., Ohlrogge, J., 2013. Biochemical pathways in seed oil synthesis. Curr. Opin. Plant Biol. 16(3), 358-364.

[14] Borghi, M., Xie, D.Y., 2016. Tissue-specific production of limonene in Camelina sativa with the Arabidopsis promoters of genes BANYULS and FRUITFULL. Planta. 243(2), 549-561.

[15] Brittaine, R., Lutaladio, N., 2010. Jatropha: a smallholder bioenergy crop: the potential for pro-poor development. Food and Agriculture Organization of the United Nations (FAO).

[16] Buhr, T., Sato, S., Ebrahim, F., Xing, A., Zhou, Y., Mathiesen, M., Schweiger, B., Kinney, A., Staswick, P., Clemente, T., 2002. Ribozyme termination of RNA transcripts down-regulate seed fatty acid genes in transgenic soybean. Plant J. 30(2), 155-163.

[17] Cao, J., Schneeberger, K., Ossowski, S., Günther, T., Bender, S., Fitz, J., Koenig, D., Lanz, C., Stegle, O., Lippert, C., Wang, X., 2011. Wholegenome sequencing of multiple Arabidopsis thaliana populations. Nat. Genet. 43, 956-963.

[18] Cartagena, J.A., Seki, M., Tanaka, M., Yamauchi, T., Sato, S., Hirakawa, H., Tsuge, T., 2014. Gene expression profiles in Jatropha under drought stress and during recovery. Plant Mol. Biol. Rep. 33(4), 1075-1087.

[19] Castro Gonzáles, N.F., 2016. International experiences with the cultivation of Jatropha curcas for biodiesel production. Energy. 112, 1245-1258.
[20] Ceasar, S.A., Ignacimuthu, S., 2011. Applications of biotechnology and biochemical engineering for the improvement of Jatropha and Biodiesel: a review. Renew. Sust. Energy Rev. 15(9), 5176-5185.

[21] Cernac, A., Benning, C., 2004. WRINKLED1 encodes an AP2/EREB domain protein involved in the control of storage compound biosynthesis in Arabidopsis. Plant J. 40(4), 575-585.

[22] Chan, A.P., Crabtree, J., Zhao, Q., Lorenzi, H., Orvis, J., Puiu, D. Melake-Berhan, A., Jones, K.M., Redman, J., Chen, G., Cahoon, E.B., 2010. Draft genome sequence of the oilseed species Ricinus communis. Nat. Biotechnol. 28, 951-956.

[23] Chen, Y., Zhou, X.R., Zhang, Z.J., Dribnenki, P., Singh, S., Green, A., 2015. Development of high oleic oil crop platform in flax through RNAi-mediated multiple FAD2 gene silencing. Plant Cell Rep. 34(4), 643-653

[24] Chhikara, S., Abdullah, H.M., Akbari, P., Schnell, D., Dhankher, O.P., 2017. Engineering Camelina sativa (L.) Crantz for enhanced oil and seed yields by combining diacylglycerol acyltransferase 1 and glycerol-3-phosphate dehydrogenase expression. Plant Biotechnol. J. 16(5), 1034-1045.

[25] Chua, N.H., Kim, M.J., Yang, S.W., 2017. Gene silencing of sugardependent 1 in Jatropha curcas. U.S. patent 9, 650,644.

[26] Ciubota-Rosie, C., Ruiz, J.R., Ramos, M.J., Pérez, Á., 2013. Biodiesel from Camelina sativa: a comprehensive characterization. Fuel. 105, 572-577

[27] Costa, G.G., Cardoso, K.C., Del Bem, L.E., Lima, A.C., Cunha, M.A., de Campos-Leite, L., Vicentini, R., Papes, F., Moreira, R.C. Yunes, J.A., Campos, F.A., Da Silva, M.J., 2010. Transcriptome analysis of the oil-rich seed of the bioenergy crop Jatropha curcas L. BMC Genomics. 11, 462.

[28] Dalal, J., Lopez, H., Vasani, N.B., Hu, Z., Swift, J.E., Yalamanchili, R., Dvora, M., Lin, X., Xie, D., Qu, R., Sederoff, H.W., 2015. A photorespiratory bypass increases plant growth and seed yield in biofuel crop Camelina sativa. Biotechnol. Biofuels. 8, 1-22.

[29] del Pilar Rodriguez, M., Brzezinski, R., Faucheux, N., Heitz, M. 2016. Enzymatic transesterification of lipids from microalgae into biodiesel: a review. AIMS Energy. 4(6), 817-855.

[30] Demirbas, A., 2009. Progress and recent trends in biodiesel fuels Energy Convers. Manage. 50(1), 14-34.

[31] Divakara, B., Upadhyaya, H., Wani, S., Gowda, C., 2010. Biology and genetic improvement of Jatropha curcas L.: a review. Appl Energy. 87(3), 732-742

[32] Durrett, T.P., Benning, C., Ohlrogge, J., 2008. Plant triacylglycerols as feedstocks for the production of biofuels. Plant J. 54(4), 593-607.

[33] Eastmond, P.J., 2007. MONODEHYDROASCORBATE REDUCTASE4 is required for seed storage oil hydrolysis and postgerminative growth in Arabidopsis. Plant Cell. 19(4), 13761387.

[34] Eastmond, P.J., 2006. SUGAR-DEPENDENT1 encodes a patatin domain triacylglycerol lipase that initiates storage oil breakdown in germinating Arabidopsis seeds. Plant Cell. 18(3), 665-675.

[35] Edrisi, S.A., Dubey, R.K., Tripathi, V., Bakshi, M., Srivastava, P. Jamil, S., Singh, H.B., Singh, N., Abhilash, P.C., 2015. Jatropha curcas L.: a crucified plant waiting for resurgence. Renew. Sust. Energy. Rev. 41, 855-862.

[36] Enjalbert, J.N., Zheng, S., Johnson, J.J., Mullen, J.L., Byrne, P.F. McKay, J.K., 2013. Brassicaceae germplasm diversity for agronomic and seed quality traits under drought stress. Ind. Crops Prod. 47, 176185.

[37] Eswaran, N., Parameswaran, S., Anantharaman, B., Kumar, G.R.K. Sathram, B., Johnson, T.S., 2012. Generation of an expressed sequence tag (EST) library from salt-stressed roots of Jatropha curcas for identification of abiotic stress-responsive genes. Plant Biol. 14(3), 428-437.

[38] Ferrie, A.M.R., Bethune, T.D., 2011. A microspore embryogenesis protocol for Camelina sativa, a multi-use crop. Plant Cell Tissue Organ Cult. 106(3), 495-501

[39] Franco, M.C., Gomes, K.A., de Carvalho Filho, M.M., Harakava, R. Carels, N., Siqueira, W.J., Latado, R.R., de Argollo Marques, D., 2016. Agrobacterium-mediated transformation of Jatropha curcas leaf explants with a fungal chitinase gene. Afr. J. Biotechnol. 15(37), 
2006-2016.

[40] Golkar, P., 2014. Breeding improvements in safflower ('Carthamus tinctorius' L.): a review. Aust. J. Crop Sci. 8(7), 1079.

[41] Grover, A., Patade, V.Y., Kumari, M., Gupta, S.M., Arif, M., Ahmed, Z., 2013. Omics approaches in biofuel production for a green environment. OMICS: applications in biomedical, agricultural, and environmental sciences. CRC Press, Taylor and Francis Group, Boca Raton. 623-636.

[42] Gu, K., Mao, H., Yin, Z., 2014. Production of marker-free transgenic Jatropha curcas expressing hybrid Bacillus thuringiensis $\delta$-endotoxin CrylAb/1Ac for resistance to larvae of tortrix moth (Archips micaceanus). Biotechnol. Biofuels. 7, 68.

[43] Gu, K., Tian, D., Mao, H., Wu, L., Yin, Z., 2015. Development of marker-free transgenic Jatropha curcas producing curcin-deficient seeds through endosperm-specific RNAi-mediated gene silencing. BMC Plant Biol. 15, 242.

[44] Gudeta, T.B., 2016. Chemical composition, bio-diesel potential and uses of Jatropha curcas L. (Euphorbiaceae). Am. J. Agric. For. 4(2), 35-48.

[45] Han, X., Liang, C.F., Li, T.Q., Wang, K., Huang, H.G., Yang, X.E., 2013. Simultaneous removal of cadmium and sulfamethoxazole from aqueous solution by rice straw biochar. J. Zhejiang Univ. Sci. 14(7), 640649.

[46] Haslam, R.P., Sayanova, O., Kim, H.J., Cahoon, E.B., Napier, J.A., 2016. Synthetic redesign of plant lipid metabolism. Plant J. 87(1), 76-86.

[47] Haun, W., Coffman, A., Clasen, B.M., Demorest, Z.L., Lowy, A., Ray, E., Retterath, A., Stoddard, T., Juillerat, A., Cedrone, F., Mathis, L., Voytas, D.F., Zhang, F., 2014. Improved soybean oil quality by targeted mutagenesis of the fatty acid desaturase 2 gene family. Plant Biotechnol. J. 12(7), 934-940.

[48] Hegde, K., Chandra, N., Sarma, S.J., Brar, S.K., Veeranki, V.D., 2015. Genetic engineering strategies for enhanced biodiesel production. Mol. Biotechnol. 57(7), 606-624.

[49] Heydarian, Z., Yu, M., Gruber, M., Glick, B.R., Zhou, R., Hegedus, D.D., 2016. Inoculation of soil with plant growth promoting bacteria producing 1-aminocyclopropane-1-carboxylate deaminase or expression of the corresponding acdS gene in transgenic plants increases salinity tolerance in Camelina sativa. Front. Microbiol. 7, 1-17.

[50] Hirakawa, H., Tsuchimoto, S., Sakai, H., Nakayama, S., Fujishiro, T., Kishida, Y., et al., 2012. Upgraded genomic information of Jatropha curcas L. Plant Biotechnol. 29(2), 123-130.

[51] Hu, Z., Wu, Q., Dalal, J., Vasani, N., Lopez, H.O., Sederoff, H.W., Qu, R., 2017. Accumulation of medium-chain, saturated fatty acyl moieties in seed oils of transgenic Camelina sativa. PLoS One. 12, 1-14.

[52] Ivarson, E., Leiva-Eriksson, N., Ahlman, A., Kanagarajan, S., Bülow, L., Zhu, L.H., 2017. Effects of overexpression of WRII and hemoglobin genes on the seed oil content of Lepidium campestre. Front. Plant Sci. 7, 2032.

[53] Jaganath, B., Subramanyam, K., Mayavan, S., Karthik, S., Elayaraja, D., Udayakumar, R., Manickavasagam, M., Ganapathi, A., 2014. An efficient in planta transformation of Jatropha curcas (L.) and multiplication of transformed plants through in vivo grafting. Protoplasma. 251(3), 591-601.

[54] Jakob, K., Zhou, F., Paterson, A.H., 2009. Genetic improvement of $\mathrm{C}_{4}$ grasses as cellulosic biofuel feedstocks. In Vitro Cell. Dev. Biol. Plant. 45(3), 291-305.

[55] Jha, B., Mishra, A., Jha, A., Joshi, M., 2013. Developing transgenic Jatropha using the SbNHXI gene from an extreme halophyte for cultivation in saline wasteland. PLoS One. 8(8), e71136.

[56] Jiang, W.Z., Henry, I.M., Lynagh, P.G., Comai, L., Cahoon, E.B., Weeks, D.P., 2017. Significant enhancement of fatty acid composition in seeds of the allohexaploid, Camelina sativa, using CRISPR/Cas9 gene editing. Plant Biotechnol. J. 15(5), 648-657.

[57] Jiang, Q., Yen, S.H., Stiller, J., Edwards, D., Scott, P.T., Gresshoff, P.M., 2012. Genetic, biochemical, and morphological diversity of the legume biofuel tree Pongamia pinnata. Plant Genet. Genom. Biotechnol. 1(3), 54-67.

[58] Joshi, K., Selig, P., Saya, I.I., Peter, M., Nalam, V.J., 2015. Engineering a host defense regulatory gene, PHYTOALEXIN DEFICIENT4 (PAD4) for enhancing resistance to soybean aphid. Stud. Res. Creative Endeavor Symp. Indiana University.
[59] Joshi, M., Mishra, A., Jha, B., 2011. Efficient genetic transformation of Jatropha curcas L. by microprojectile bombardment using embryo axes. Ind. Crops Prod. 33(1), 67-77.

[60] Kallio, P., Pásztor, A., Akhtar, M.K., Jones, P.R., 2014. Renewable jet fuel. Curr. Opin. Biotechnol. 26, 50-55.

[61] Kelly, A.A., Shaw, E., Powers, S.J., Kurup, S., Eastmond, P.J., 2013. Suppression of the SUGAR-DEPENDENT1 triacylglycerol lipase family during seed development enhances oil yield in oilseed rape (Brassica napus L.). Plant Biotechnol. J. 11(3), 355-361.

[62] Khemkladngoen, N., Cartagena, J., Fukui, K., 2011. Physica wounding-assisted Agrobacterium-mediated transformation for juvenile cotyledons of a biodiesel producing plant, Jatropha curcas L. Plant Biotechnol. Rep. 5(3), 235-243.

[63] Kim, H., Park, J.H., Kim, D.J., Kim, A.Y., Suh, M.C., 2016 Functional analysis of diacylglycerol acyltransferasel genes from Camelina sativa and effects of CSDGATIB overexpression on seed mass and storage oil content in C. sativa. Plant Biotechnol. Rep. 10(3), 141-153.

[64] Kim, H.J., Silva, J.E., Vu, H.S., Mockaitis, K., Nam, J.W., Cahoon, E.B., 2015. Toward production of jet fuel functionality in oilseeds: identification of FatB acyl-acyl carrier protein thioesterases and evaluation of combinatorial expression strategies in Camelina seeds. J. Exp. Bot. 66, 4251-4265.

[65] Kim, M.J., Yang, S.W., Mao, H.Z., Veena, S.P., Yin, J.L., Chua, N.H., 2014. Gene silencing of Sugar-dependent 1 (JCSDPI), encoding a patatin-domain triacylglycerol lipase, enhances seed oil accumulation in Jatropha curcas. Biotechnol. Biofuel. 7, 1-16.

[66] King, A.J., He, W., Cuevas, J.A., Freudenberger, M., Ramiaramanana, D., Graham, I.A., 2009. Potential of Jatropha curcas as a source of renewable oil and animal feed. J. Exp. Bot. 60(10), 2897-2905.

[67] King, A.J., Li, Y., Graham, I.A. 2011. Profiling the developing Jatropha curcas L. seed transcriptome by pyrosequencing. Bioenergy Res. 4(3), 211-221.

[68] Krohn, B.J., Fripp, M., 2012. A life cycle assessment of biodiesel derived from the "niche filling" energy crop camelina in the USA. Appl. Energy. 92, 92-98.

[69] Kumar, N., Singh, A.S., Kumari, S., Reddy, M.P., 2015 Biotechnological approaches for the genetic improvement of Jatropha curcas L.: a biodiesel plant. Ind. Crop Prod. 76, 817-828.

[70] Kumar, N., Anand, K.G.V., Pamidimarri, D.V.N.S., Sarkar, T. Reddy, M.P., Radhakrishnan, T., Kaul, T., Reddy, M.K., Sopori, S.K., 2010. Stable genetic transformation of Jatropha curcas via Agrobacterium tumefaciens-mediated gene transfer using leaf explants. Ind. Crop Prod. 32(1), 41-47.

[71] Laviola, B.G., Rodrigues, E.V., Teodoro, P.E., de Azevedo Peixoto, L., Bhering, L.L., 2017. Biometric and biotechnology strategies in Jatropha genetic breeding for biodiesel production. Renew. Sustain. Energy Rev. 76, 894-904.

[72] Lee, R.A., Lavoie, J.M., 2013. From first-to third-generation biofuels: challenges of producing a commodity from a biomass of increasing complexity. Anim. Front. 3(2), 6-11.

[73] Lee, S.B., Kim, H., Kim, R.J., Suh, M.C., 2014. Overexpression of Arabidopsis MYB96 confers drought resistance in Camelina sativa via cuticular wax accumulation. Plant Cell Rep. 33(9), 1535-1546.

[74] Li, M., Li, H., Jiang, H., Pan, X., Wu, G., 2008. Establishment of an Agrobacteriuim-mediated cotyledon disc transformation method for Jatropha curcas. Plant Cell Tissue Organ Cult. 92(2), 173-181.

[75] Li, C., Luo, L., Fu, Q., Niu, L., Xu, Z.F., 2014. Isolation and functional characterization of JCFT, a FLOWERING LOCUS T (FT) homologous gene from the biofuel plant Jatropha curcas. BMC Plant Biol. 14, 125 .

[76] Li, Y., Huang, Y., Du, W., Dai, L., Liu, D., 2015. Combined phospholipase and lipase catalysis for biodiesel production from phospholipids-containing oil. Biotechnol. Bioprocess Eng. 20(5), 965-970.

[77] Li, M., Wei, F., Tawfall, A., Tang, M., Saettele, A., Wang, X., 2015 Overexpression of patatin-related phospholipase AIII $\delta$ altered plant growth and increased seed oil content in Camelina . Plant Biotechnol. J. 13(6), 766-778. 
[78] Lin, Z., An, J., Wang, J., Niu, J., Ma, C., Wang, L., Yuan, G., Shi, L., Liu, L., Zhang, J., Zhang, Z., 2017. Integrated analysis of 454 and Illumina transcriptomic sequencing characterizes carbon flux and energy source for fatty acid synthesis in developing Lindera glauca fruits for woody biodiesel. Biotechnol. Biofuels. 10, 134.

[79] Liu, J., Rice, A., Mcglew, K., Shaw, V., Park, H., Clemente, T., Pollard, M., Ohlrogge, J., Durrett, T.P., 2015. Metabolic engineering of oilseed crops to produce high levels of novel acetyl glyceride oils with reduced viscosity, freezing point and calorific value. Plant Biotechnol. J. 13(6), 858-865.

[80] Liu, Q., Guo, Q., Akbar, S., Zhi, Y., El Tahchy, A., Mitchell, M., Li, Z., Shrestha, P., Vanhercke, T., Ral, J.P., Liang, G., Wang, M.B., White, R., Larkin, P., Singh, S., Petrie, J., 2017. Genetic enhancement of oil content in potato tuber (Solanum tuberosum L.) through an integrated metabolic engineering strategy. Plant Biotechnol. J. 15(1), 56-67.

[81] Liu, X., Brost, J., Hutcheon, C., Guilfoil, R., Wilson, A.K., Leung, S., Shewmaker, C.K., Rooke, S., Nguyen, T., Kiser, J., de Rocher, J., 2012. Transformation of the oilseed crop Camelina sativa by Agrobacteriummediated floral dip and simple large-scale screening of transformants. In Vitro Cell. Dev. Biol. Plant. 48(5), 462-468.

[82] Lu, C., Kang, J., 2008. Generation of transgenic plants of a potential oilseed crop Camelina sativa by Agrobacterium-mediated transformation. Plant Cell Rep. 27(2), 273-278.

[83] Merkouropoulos, G., Kapazoglou, A., Drosou, V., Jacobs, E., Krolzig, A., Papadopoulos, C., Hilioti, Z., 2016. Dwarf hybrids of the bioenergy crop Ricinus communis suitable for mechanized harvesting reveal differences in morpho-physiological characteristics and seed metabolic profiles. Euphytica. 210(2), 207-219.

[84] Misra, A., Khan, K., Niranjan, A., Nath, P., Sane, V.A., 2013. Overexpression of JcDGAT1 from Jatropha curcas increases seed oil levels and alters oil quality in transgenic Arabidopsis thaliana. Phytochem. 96, $37-45$.

[85] Misra, P., Toppo, D.D., Mishra, M.K., Saema, S., Singh, G., 2012. Agrobacterium tumefaciens-mediated transformation protocol of Jatropha curcas L. using leaf and hypocotyl segments. J. Plant Biochem. Biotechnol. 21(1), 128-133

[86] Moniruzzaman, M., Yaakob, Z., Khatun, R., 2016. Biotechnology for Jatropha improvement: a worthy exploration. Renew. Sust. Energy Rev. 54, 1262-1277.

[87] Montes, J.M., Melchinger, A.E., 2016. Domestication and Breeding of Jatropha curcas L. Trends Plant Sci. 21(12), 1045-1057.

[88] Morineau, C., Bellec, Y., Tellier, F., Gissot, L., Kelemen, Z., Nogué, F., Faure, J.D., 2017. Selective gene dosage by CRISPR-Cas9 genome editing in hexaploid Camelina sativa. Plant Biotechnol. J. 15(6), 729739.

[89] Mudalkar, S., Golla, R., Ghatty, S., Reddy, A.R., 2014. De novo transcriptome analysis of an imminent biofuel crop, Camelina sativa $\mathrm{L}$. using Illumina GAIIX sequencing platform and identification of SSR markers. Plant Mol. Biol. 84(1-2), 159-171.

[90] Nanasato, Y., Kido, M., Kato, A., Ueda, T., Suharsono, S., Widyastuti, U., Tsujimoto, H., Akashi, K., 2015. Efficient genetic transformation of Jatropha curcas L. by means of vacuum infiltration combined with filterpaper wicks. In Vitro Cell. Dev. Biol. Plant. 51(4), 399-406.

[91] Natarajan, P., Kanagasabapathy, D., Gunadayalan, G., Panchalingam, J., Sugantham, P.A., Singh, K.K., Madasamy, P., 2010. Gene discovery from Jatropha curcas by sequencing of ESTs from normalized and fulllength enriched cDNA library from developing seeds. BMC Genomics. 11,606 .

[92] Nayanakantha, N.C., Rawat, S., Ali, S., Grover, A., 2014. Defense gene induction in Camelina sativa upon Alternaria brassicae challenge. Indian Phytopathol. 67(3).

[93] Narasimhulu, S.B., Kirti, P.B., Bhatt, S.R., Prakash, S., Chopra, V.L., 1994. Intergeneric protoplast fusion between Brassica carinata and Camelina sativa. Plant Cell Rep. 13(11), 657-660.

[94] Nguyen, H.T., Mishra, G., Whittle, E., Pidkowich, M.S., Bevan, S.A., Merlo, A.O., Walsh, T.A., Shanklin, J., 2010. Metabolic engineering of seeds can achieve levels of $\omega-7$ fatty acids comparable with the highest levels found in natural plant sources. Plant Physiol. 154, 1897-1904.

[95] Nguyen, H.T., Park, H., Koster, K.L., Cahoon, R.E., Nguyen, H.T.M., Shanklin, J., Clemente, T.E., Cahoon, E.B., 2015. Redirection of metabolic flux for high levels of omega-7 monounsaturated fatty acid accumulation in camelina seeds. Plant Biotechnol. J. 13(1), 38-50.

[96] Nie, W-X., Xu, L., Yu, B-j., 2014. A putative soybean GmsSOS1 confers enhanced salt tolerance to transgenic Arabidopsis sos 1-1 mutant. Protoplasma. 252(1), 127-134.

[97] OECD, 2012. OECD Environmental Outlook to 2050: the Consequences of Inaction.

[98] Okuzaki, A., Ogawa, T., Koizuka, C., Kaneko, K., Inaba, M. Imamura, J., Koizuka, N., 2018. CRISPR/Cas9-mediated genome editing of the fatty acid desaturase 2 gene in Brassica napus. Plant Physiol. Biochem. 131, 63-69.

[99] Ozseyhan, M.E., Kang, J., Mu, X., Lu, C., 2018. Mutagenesis of the FAE1 genes significantly changes fatty acid composition in seeds of Camelina sativa. Plant Physiol. Biochem. 123, 1-7.

[100] Pan, J., Fu, Q., Xu, Z.F., 2010. Agrobacterium tumefaciens-mediated transformation of biofuel plant Jatropha curcas using kanamycin selection. Afr. J. Biotechnol. 9(39), 6477-6481.

[101] Pan, B.Z., Luo, Y., Song, L., Chen, M.S., Li, J.L., Xu, Z.F., 2016. Thidiazuron increases fruit number in the biofuel plant Jatropha curcas by promoting pistil development. Ind. Crops Prod. 81, 202 210.

[102] Park, W., Feng, Y., Ahn, S.J., 2014. Alteration of leaf shape, improved metal tolerance, and productivity of seed by overexpression of CsHMA3 in Camelina sativa. Biotechnol Biofuels. 7(1), 96

[103] Park, W., Feng, Y., Kim, H., Suh, M.C., Ahn, S.J., 2015. Changes in fatty acid content and composition between wild type and CsHMA3 overexpressing Camelina sativa under heavy-metal stress. Plant cell Rep. 34(9), 1489-1498.

[104] Patade, V.Y., Khatri, D., Kumar, K., Grover, A., Kumari, M., Gupta, S.M., Kumar, D., Nasim, M., 2014. RNAi mediated curcin precursor gene silencing in Jatropha (Jatropha curcas L.). Mol. Biol. Rep. 41(7), 4305-4312.

[105] Pootakham, W., Jomchai, N., Ruang-areerate, P., Shearman, J.R. Sonthirod, C., Sangsrakru, D., Tragoonrung, S., Tangphatsornruang, S., 2015. Genome-wide SNP discovery and identification of QTL associated with agronomic traits in oil palm using genotyping-bysequencing (GBS). Genomics. 105(5-6), 288-295.

[106] Price, G.D., Badger, M.R., Woodger, F.J., Long, B.M., 2008. Advances in understanding the cyanobacterial $\mathrm{CO}_{2}$-concentratingmechanism (CCM): functional components, $\mathrm{Ci}$ transporters, diversity, genetic regulation and prospects for engineering into plants. J. Exp. Bot. 59(7), 1441-1461

[107] Purkayastha, J., Sugla, T., Paul, A., Solleti, S.K., Mazumdar, P., Basu, A., Mohommad, A., Ahmed, Z., Sahoo, L., 2010. Efficient in vitro plant regeneration from shoot apices and gene transfer by particle bombardment in Jatropha curcas. Biol. Plant. 54(1), 13-20.

[108] Qu, J., Mao, H.Z., Chen, W., Gao, S.Q., Bai, Y.N., Sun, Y.W., Geng, Y.F., Ye, J., 2012. Development of marker-free transgenic Jatropha plants with increased levels of seed oleic acid. Biotechnol. Biofuels. $5(1), 10$.

[109] Rahman, A.Y.A., Usharraj, A.O., Misra, B.B., Thottathil, G.P., Jayasekaran, K., Feng, Y., Hou, S., Ong, S.Y., Ng, F.L., Lee, L.S., Tan, H.S., 2013. Draft genome sequence of the rubber tree Hevea brasiliensis. BMC Genomics. 14, 75.

[110] Roesler, K., Shintani, D., Savage, L., Boddupalli, S., Ohlrogge, J., 1997. Targeting of the Arabidopsis homomeric acetyl-coenzyme a carboxylase to plastids of rapeseeds. Plant Physiol. 113(1), 75-81.

[111] Rossi, L., Borghi, M., Xie, D., 2014. August. Characterization of transgenic Camelina plants emitting isoprene. In proceedings of the 53rd annual meeting of the phytochemical society of North America.

[112] Roy Choudhury, S., Riesselman, A.J., Pandey, S., 2014. Constitutive or seed-specific overexpression of Arabidopsis G-protein $\gamma$ subunit 3 (AGG3) results in increased seed and oil production and improved stress tolerance in Camelina sativa. Plant Biotechnol. J. 12(1), 4959.

[113] Ruiz-Lopez, N., Haslam, R.P., Napier, J.A., Sayanova, O., 2014 Successful high-level accumulation of fish oil omega-3 long-chain polyunsaturated fatty acids in a transgenic oilseed crop. Plant J. 77(2), 198-208 
[114] Sainger, M., Jaiwal, A., Sainger, P.A., Chaudhary, D., Jaiwal, R., Jaiwal, P.K., 2017. Advances in genetic improvement of Camelina sativa for biofuel and industrial bio-products. Renew. Sust. Energy Rev. 68(1), 623-637.

[115] Safarnejad, M.R., Salehi Jouzani, G., Tabatabaie, M., Twyman, R.M., Schillberg, S., 2011. Antibody-mediated resistance against plant pathogens. Biotechnol. Adv. 29(6), 961-971.

[116] Salehi Jouzani, G., 2012. Risk assessment of GM crops; challenges in regulations and science. Biosaf. 1, 113.

[117] Salehi Jouzani, G., Taherzadeh, M.J., 2015. Advances in consolidated bioprocessing systems for bioethanol and butanol production from biomass: a comprehensive review. Biofuel Res. J. 2(1), 152-195.

[118] Salehi Jouzani, G., Goldenkova, I.V., Piruzian, E.S., 2008. Expression of hybrid cry3aM-licBM2 genes in transgenic potatoes (Solanum tuberosum). Plant Cell Tissue Organ Cult. 92(3), 321-325.

[119] Salehi Jouzani, G., Komakhin, R.A., Piruzian, E.S., 2005. Comparative study of the expression of the native, modified, and hybrid cry3a genes of Bacillus thuringiensis in prokaryotic and eukaryotic cells. Russ. J. Genet. 41(2), 116-121

[120] Salehi Jouzani, G., Valijanian, E., Sharafi, R., 2017. Bacillus thuringiensis: a successful insecticide with new environmental features and tidings. Appl. Microbiol. Biotechnol. 101(7), 2691-2711.

[121] Sato, S., Hirakawa, H., Isobe, S., Fukai, E., Watanabe, A., Kato, M., Kawashima, K., Minami, C., Muraki, A., Nakazaki, N., Takahashi, C., 2011. Sequence analysis of the genome of an oil-bearing tree, Jatropha curcas L. DNA Res. 18(1), 65-76.

[122] Schmutz, J., Cannon, S.B., Schlueter, J., Ma, J., Mitros, T., Nelson, W., Hyten, D.L., Song, Q., Thelen, J.J., Cheng, J., Xu, D., 2010. Genome sequence of the palaeopolyploid soybean. Nature. 463(7278), 178-183.

[123] Selim, H., 2015. Handbook of Bioenergy. https://10.1007\%2F978-3319-20092-7.

[124] Shen, B., Allen, W.B., Zheng, P., Li, C., Glassman, K., Ranch, J., Nubel, D., Tarczynski, M.C., 2010. Expression of $\mathrm{ZmLEC}_{1}$ and $\mathrm{ZmWRI}_{1}$ increases seed oil production in maize. Plant Physiol. 153(3), 980-987.

[125] Singh, A.S., Kumari, S., Modi, A.R., Gajera, B.B., Narayanan, S., Kumar, N., 2015. Role of conventional and biotechnological approaches in genetic improvement of castor (Ricinus communis L.). Ind. Crops Prod. 74, 55-62

[126] Shi, H., Ishitani, M., Kim, C., Zhu, J.K., 2000. The Arabidopsis thaliana salt tolerance gene SOS1 encodes a putative $\mathrm{Na}^{+} / \mathrm{H}^{+}$antiporter. Proc. Natl. Acad. Sci. U.S.A. 97(12), 6896-6901.

[127] Singh, V., Nimbkar, N., 2006. Chapter 6 Safflower (Carthamus Genet. Resour. Chromosom. Eng tinctorius L). Crop Improv. 19, 167-194.

[128] Sinha, P., Islam, M.A., Negi, M.S., Tripathi, S.B., 2016. Analysis of genetic diversity and fatty acid composition in a prebreeding material of Jatropha. J. Plant Biochem. Biotechnol. 25(1), 111-116.

[129] Snapp, A.R., Kang, J., Qi, X., Lu, C., 2014. A fatty acid condensing enzyme from Physaria fendleri increases hydroxy fatty acid accumulation in transgenic oilseeds of Camelina sativa. Planta. 240(3), 599-610.

[130] Sood, A., Chauhan, R.S., 2015. Regulation of FA and TAG biosynthesis pathway genes in endosperms and embryos of high and low oil content genotypes of Jatropha curcas L. Plant Physiol. Biochem. 94, 253-267.

[131] Staton, S.E., Bakken, B.H., Blackman, B.K., Chapman, M.A., Kane, N.C., Tang, S., Ungerer, M.C., Knapp, S.J., Rieseberg, L.H., Burke, J.M., 2012. The sunflower (Helianthus annuus L.) genome reflects a recent history of biased accumulation of transposable elements. Plant J. 72(1), 142-153.

[132] Sun, Y., Wang, C., Wang, N., Jiang, X., Mao, H., Zhu, C., Wen, F., Wang, X., Lu, Z., Yue, G., Xu, Z., 2017. Manipulation of Auxin Response Factor 19 affects seed size in the woody perennial Jatropha Curcas. Sci. Rep. 7, 40844.

[133] Tabatabaei, M., Tohidfar, M., Salehi Jouzani, G., Safarnejad, M., Pazouki, M., 2011. Biodiesel production from genetically engineered microalgae: future of bioenergy in Iran. Renew. Sust. Energy Rev. 15(4), 1918-1927.

[134] Taher, H., Al-Zuhair, S., 2017. The use of alternative solvents in enzymatic biodiesel production: a review. Biofuels, Bioprod. Biorefin. 11(1), 168-194.

[135] Tang, M., Liu, X., Deng, H., Shen, S., 2011. Over-expression of
JcDREB, a putative AP2/EREBP domain-containing transcription factor gene in woody biodiesel plant Jatropha curcas, enhances salt and freezing tolerance in transgenic Arabidopsis thaliana. Plant Sci. 181(6), 623-631.

[136] Tian, Y., Zhang, M., Hu, X., Wang, L., Dai, J., Xu, Y., Chen, F. 2016. Over-expression of CYP78A98, a cytochrome P450 gene from Jatropha curcas L., increases seed size of transgenic tobacco. Electron. J. Biotechnol. 19, 15-22.

[137] Tohidfar, M., Zare, N., Salehi Jouzani, G., Eftekhari, S.M., 2013 Agrobacterium-mediated transformation of alfalfa (Medicago sativa) using a synthetic cry $3 a$ gene to enhance resistance against alfalfa weevil. Plant Cell Tiss. Organ Cult. (PCTOC). 113(2), 227-235.

[138] Tsuchimoto, S., Cartagena, J., Khemkladngoen, N., Singkaravanit, S., Kohinata, T., Wada, N., Sakai, H., Morishita, Y., Suzuki, H., Shibata, D., Fukui, K., 2012. Development of transgenic plants in jatropha with drought tolerance. Plant Biotechnol. 29(2), 137-143.

[139] Tsuchimoto, S. ed., 2017. The Jatropha Genome. Springer.

[140] Valliyodan, B., Ye, H., Song, L., Murphy, M., Grover Shannon, J., Nguyen, H.T., 2017. Genetic diversity and genomic strategies for improving drought and waterlogging tolerance in soybeans. J. Exp. Bot. 68(8), 1835-1849.

[141] van Erp, H., Bates, P.D., Burgal, J., Shockey, J., Browse, J., 2011 Castor phospholipid: diacylglycerol acyltransferase facilitates efficient metabolism of hydroxy fatty acids in transgenic Arabidopsis. Plant Physiol. 155, 683-693.

[142] Vanhercke, T., El Tahchy, A., Shrestha, P., Zhou, X.R., Singh, S.P. Petrie, J.R., 2013. Synergistic effect of WRI1 and DGAT1 coexpression on triacylglycerol biosynthesis in plants. FEBS Lett. 587(4), 364-369.

[143] Vigeolas, H., Waldeck, P., Zank, T., Geigenberger, P., 2007. Increasing seed oil content in oil-seed rape (Brassica napus L.) by over-expression of a yeast glycerol-3-phosphate dehydrogenase under the control of a seed-specific promoter. Plant Biotechnol. J. 5(3), 431-441

[144] Vollmann, J., Eynck, C., 2015. Camelina as a sustainable oilseed crop: contributions of plant breeding and genetic engineering. Biotechnol. J. 10(4), 525-535.

[145] Wang, C.M., Liu, P., Sun, F., Li, L., Liu, P., Ye, J., Yue, G.H., 2012 Isolation and identification of MiRNAs in Jatropha curcas. Int. J. Biol. Sci. 8(3), 418-429

[146] Wang, X., Wang, H., Wang, J., Sun, R., Wu, J., Liu, S., Bai, Y., Mun, J.H., Bancroft, I., Cheng, F., Huang, S., 2011. The genome of the mesopolyploid crop species Brassica rapa. Nat. Genet. 43, 10351039.

[147] Wang, L., Gao, J., Qin, X., Shi, X., Luo, L., Zhang, G., Yu, H., Li, C., Hu, M., Liu, Q., Xu, Y., Chen, F., 2015. JcCBF2 gene from Jatropha curcas improves freezing tolerance of Arabidopsis thaliana during the early stage of stress. Mol. Biol. Rep. 42(5), 937-945.

[148] Weselake, R.J., Shah, S., Tang, M., Quant, P.A., Snyder, C.L., Furukawa-Stoffer, T.L., Zhu, W., Taylor, D.C., Zou, J., Kumar, A. Hall, L., Laroche, A., Rakow, G., Raney, P., Moloney, M.M., Harwood, J.L., 2008. Metabolic control analysis is helpful for informed genetic manipulation of oilseed rape (Brassica napus) to increase seed oil content. J. Exp. Bot. 59(13), 3543-3549.

[149] Wu, P., Zhou, C., Cheng, S., Wu, Z., Lu, W., Han, J., Chen, Y., Chen, Y., Ni, P., Wang, Y., Xu, X., 2015. Integrated genome sequence and linkage map of physic nut (Jatropha curcas L.), a biodiesel plant. Plant J. 81, 810-821.

[150] Wu, P.Z., Li, J., Wei, Q., Zeng, L., Chen, Y.P., Li, M.R., Jiang, H.W. Wu, G.J., 2009. Cloning and functional characterization of an acylacyl carrier protein thioesterase (JcFATB1) from Jatropha curcas. Tree Physiol. 29(10), 1299-1305.

[151] Xiong, W., Wei, Q., Wu, P., Zhang, S., Li, J., Chen, Y., Li, M., Jiang, H., Wu, G., 2017. Molecular cloning and characterization of two $\beta$ ketoacyl-acyl carrier protein synthase I genes from Jatropha curcas L. J. Plant Physiol. 214, 152-160.

[152] Yang, D., Zhang, H., Peng, K., Chen, L., He, H., Huang, X., Qin, J. He, G., Zhang, D., 2016. Differential gene regulation of lipid synthesis in the developing seeds of two biodiesel tree species, Jatropha and Vernicia. Int. J. Agri. Biol. 18(6), 1143-1152. 
[153] Ye, J., Qu, J., Mao, H.Z., Ma, Z.G., Rahman, N.E.B., Bai, C., Chen, W., Jiang, S.Y., Ramachandran, S., Chua, N.H., 2014. Engineering geminivirus resistance in Jatropha curcus. Biotechnol. Biofuels. 7(1), 149.

[154] Yemets, A.I., Boychuk, Y.N., Shysha, E.N., Rakhmetov, D.B., Blume, Y.B., 2013. Establishment of in vitro culture, plant regeneration, and genetic transformation of Camelina sativa. Cytol. Genet. 47(3), 138-144.

[155] Yu, X.H., Prakash, R.R., Sweet, M., Shanklin, J., 2014. Co-expressing Escherichia coli cyclopropane synthase with Sterculia foetida lysophosphatidic acid acyltransferase enhances cyclopropane fatty acid accumulation. Plant Physiol. 164, 455-465.

[156] Yue, G.H., Sun, F., Liu, P., 2013. Status of molecular breeding for improving Jatropha curcas and biodiesel. Renew. Sust. Energy Rev. 26, 332-343.

[157] Zahed, O., Salehi Jouzani, G., Abbasalizadeh, S., Khodaiyan, F., Tabatabaei, M., 2016. Continuous co-production of ethanol and xylitol from rice straw hydrolysate in a membrane bioreactor. Folia Microbiol. 61(3), 179-189.
[158] Zakharchenko, N.S., Kaliaeva, M.A., Bur'ianov Ia, I., 2013 Expression of cecropin P1 gene increases resistance of Camelina sativa (L.) plants to microbial phytopathogenes. Russ. J. Genet. 49(5), 523-529

[159] Zhang, Y., Yu, L., Yung, K.F., Leung, D.Y., Sun, F., Lim, B.L. 2012. Over-expression of AtPAP2 in Camelina sativa leads to faster plant growth and higher seed yield. Biotechnol. Biofuels. 5(1), 19.

[160] Zhang, C., Zhang, L., Zhang, S., Zhu, S., Wu, P., Chen, Y., Li, M., Jiang, H., Wu, G., 2015. Global analysis of gene expression profiles in physic nut (Jatropha curcas L.) seedlings exposed to drought stress. BMC Plant Biol. 15, 17.

[161] Zou, J., Katavic, V., Giblin, E.M., Barton, D.L., MacKenzie, S.L., Keller, W.A., Hu, X., Taylor, D.C., 1997. Modification of seed oil content and acyl composition in the brassicaceae by expression of a yeast sn-2 acyltransferase gene. Plant Cell. 9(6), 909-923.

[162] Zhu, Y., Xie, L., Chen, G.Q., Lee, M.Y., Loque, D., Scheller, H.V., 2018. A transgene design for enhancing oil content in Arabidopsis and Camelina seeds. Biotechnol. Biofuels. 11, 46. 